\title{
What is a Financial Crisis? \\ Efficiently Measuring Real-Time Perceptions of Financial Market Stress with an Application to Financial Crisis Budget Cycles
}

\author{
Christopher Gandrud \\ Mark Hallerberg \\ CESIFO WORKING PAPER NO. 5632 \\ CATEGORY 7: MONETARY POLICY AND INTERNATIONAL FINANCE \\ NOVEMBER 2015 \\ An electronic version of the paper may be downloaded \\ - from the SSRN website: \\ - from the RePEc website: \\ - from the CESifo website: \\ wWw.SSRN.com \\ www.RePEc.org \\ www.CESifo-group.org/wp
}




\title{
What is a Financial Crisis? Efficiently Measuring Real-Time Perceptions of Financial Market Stress with an Application to Financial Crisis Budget Cycles
}

\begin{abstract}
Comparative quantitative research into the causes, responses to, and effects of banking crisis uses two series of crisis data: Reinhart and Rogoff (2009, 2010) and Laeven and Valencia (2013, and their predecessors). While these data sets provide broad coverage, the measures they code have several shortcomings. They are constructed post hoc and so tend to be biased towards severe crises with large government responses and away from circumstances where governments effectively calmed emerging trouble. They suffer from clear selection bias. Because they are simple dichotomous indicators of financial crisis, they do not indicate crisis severity. They use often ad hoc methods of determining when a crisis has ended. Our goal in this paper is to create a measure that is accurate, reliable, and comparable across countries, and that includes information about crisis severity. We use a kernel principal component analysis (PCA) of Economist Intelligence Unit (EIU) monthly country reports to develop a new real-time and continuous measure of perceived banking system stress. We refer to this measure as the EIU Perceptions of Financial Market Stress (FinStress) Index. We not only develop a novel indicator of financial market stress, but we also make a contribution to the wider political science and finance literatures on measurement by demonstrating how kernel PCA can be used to efficiently summarise vast quantities of qualitative texts into useful continuous cross-sectional time-series indicators. Finally, we provide an application of our measure to the political business cycle literature, with a focus on changes in debt. We demonstrate that governments reveal more of the debt created by responding to financial market stress when they are electorally safe.
\end{abstract}

JEL-Codes: C820, H620, G200, G280.

Keywords: financial crisis, political business cycles.

\author{
Christopher Gandrud* \\ City University London \\ London / United Kingdom \\ christopher.gandrud@city.ac.uk
}

\author{
Mark Hallerberg \\ Hertie School of Governance \\ Berlin / Germany \\ hallerberg@hertie-school.org
}


November 26, 2015

Thank you to Nicole Rae Baerg, Vincent Arel-Bundock, Ronen Palan, David Singer, and participants at the 2015 American Political Science Association Annual Conference, the 2015 International Political Economy Society Conference, and City University London for helpful comments. We also thank Christian Franz and Sahil Deo for early research assistance. Our research is generously supported by the Deutsche Forschungsgemeinschaft. All data and replication material can be found at: https://github.com/christophergandrud/EIUCrisesMeasure. The full FinStress Index can be downloaded into R with the rio package using:

FinStress <- rio::import("http://bit.ly/1LFEnhM"). The variable labeled C1 ma-i.e. first component moving average-is the FinStress measure discussed in this paper. 
Why and how do politicians respond to financial market stress? What are the political consequences of financial crises? These questions have attracted considerable attention following the 2007-2009 crisis, and earlier Asian financial crisis. However, most research on these topics lacks a crucial variable: a real-time indicator of the level of financial market stress that policy-makers perceived. To understand why politicians made a given choice in response to financial market stress, we need a measure of the conditions that existed as perceived in real-time. The literature on the political responses to and effects of financial crises has relied on two measures of financial crisis-Reinhart and Rogoff (2009, 2010) and Laeven and Valencia (2013, and their predecessors). They are constructed post hoc and so tend to be biased towards severe crises with large government responses and away from circumstances where governments effectively calmed emerging trouble. As such they suffer from clear selection bias. Because they are simple dichotomous indicators of financial crisis, they do not indicate crisis severity. They use often ad hoc methods of determining when a crisis has ended.

In this paper, we develop a new index of real-time perceptions of financial market stress. We create this variable using a kernel principal component analysis (PCA) of detailed qualitative data, namely monthly Economist Intelligence Unit (EIU) reports. We call it the EIU Perceptions of Financial Market Stress (FinStress) Index. This measure has several advantages over the popular measures of crisis. It is continuous instead of dichotomous, it is not a priori weighted towards crises with particular government responses, and it allows researchers to identify episodes of stress where policy-makers successfully avoided a full-blown crisis. We also make a contribution to the wider political science literature by showing how kernel PCA can be used to summarise vast quantities of qualitative texts into continuous cross-sectional time-series indicators.

We start the paper by explaining previous attempts to measure financial market crises and stress, as well as identifying areas where they could be improved. We then discuss the construction of the FinStress Index and assess its validity. We compare it to widely used previous measures of financial market stress that are based on both quantitative and qualitative data. We document theoretically interesting variation in the Index. FinStress allows us to draw conclusions about how financial market conditions differ across countries and how perceptions of financial market stress change over the course of crises. We end the paper with an example of how the Index could be used in applied research on political budget cycles. 
Table 1: Comparison of Crisis Measures' Definitions

\begin{tabular}{|c|c|c|c|}
\hline Source & $\begin{array}{l}\text { Measurement } \\
\text { Level }\end{array}$ & Periodicity & Definition of Financial Market Distress/Crisis \\
\hline $\begin{array}{l}\text { Reinhart and Ro- } \\
\text { goff (2009; 2010, } \\
\text { 11) }\end{array}$ & binary & annual & $\begin{array}{l}\text { One of two types of events: (1) bank runs } \\
\text { leading to closures, mergers, or public sec- } \\
\text { tor takeovers of one or more financial insti- } \\
\text { tution or }(2) \text { the closure, merger, takeover, or } \\
\text { large-scale government assistant-at least three } \\
\text { measures-of an important financial institution } \\
\text { marking the start of a string of similar events. }\end{array}$ \\
\hline $\begin{array}{l}\text { Laeven and Valen- } \\
\text { cia }(2013,228)\end{array}$ & binary & annual & $\begin{array}{l}\text { Meets two conditions: (1) significant sign of fi- } \\
\text { nancial distress in the banking system and (2) } \\
\text { significant banking policy intervention mea- } \\
\text { sures in response to significant losses in the } \\
\text { banking system. }\end{array}$ \\
\hline $\begin{array}{l}\text { Romer and Romer } \\
(2015,3)\end{array}$ & $\begin{array}{l}\text { ordinal ( } 0 \text { to } \\
15 \text { scale) }\end{array}$ & bi-annual & $\begin{array}{l}\text { Hand-coded perceptions of funding problems } \\
\text { and rising loan defaults in OECD Economic } \\
\text { Outlook }\end{array}$ \\
\hline
\end{tabular}




\section{Motivation}

Knowing when crises started, when they ended, and how severe they were over their course is crucial for understanding how governments choose to respond to financial market distress, the fiscal costs of these responses, and the political outcomes. Researchers working on these issues rely on two data sources of cross-country information on when a country is facing a financial crisis-Reinhart and Rogoff $(2009,2010)$ and Laeven and Valencia (2013, and their predecessors).

Reinhart and Rogoff $(2009 ; 2010,10)$ classify counties as being in crisis when they experience at least one type of event: (1) one or more bank run, closure, merger, or public sector takeover and/or (2) closure, merger, takeover or large-scale public assistance of an important financial institution that marks the start of a string of similar events. Laeven and Valencia $(2013,228)$ take a similar approach, that nonetheless explicitly emphasizes public interventions. They classify a country-year as in crisis when there is both significant distress in the banking system and policy-makers respond to the distress with significant interventions. ${ }^{1}$ Please see Table 1 for a list of the criteria these data sets use to code a given country-year as being in a crisis.

These indicators have been widely employed in the literature and are critical indicators for evaluating the political economy of financial crises. Fielding and Rewilak (2015) and Herrera, Ordoñez and Trebesch (2014) use Laeven and Valencia's indicator as a dependent variable when attempting to understand how capital flow bonanzas affect the probability of crises occurring. Keefer $(2007)$ and Rosas $(2006,2009)$ used earlier versions of the Laeven and Valencia (2013) data set to identify periods of crisis and to argue that electoral competitiveness affected the type of policy response, as well as in Keefer's case, the overall costs of the crisis to taxpayers. Reischmann (forthcoming) uses the Laeven and Valencia measure to examine electoral effects on "creative public budget accounting", proposing that creative accounting occurs at a higher volume during crises. Seiferling and Tareq (2015) use the Laeven and Valencia measure to find that the composition of government assets is different in crisis periods for advanced and emerging economy countries, such that advanced countries make more loans and purchase more equities in insolvent firms. Ha and Kang (2015) find using the Laeven and Valencia data set that developing country governments respond to crises with fiscal and monetary tightening, but that this is moderated by political constraints-veto players-, left-wing ideology, and upcoming elections. Gandrud (2013, 2014) and Kleibl (2013) combine the two data sources to understand how financial regulatory structures are changed in response to crises. Broz (2013) takes a

\footnotetext{
${ }^{1}$ They define 'significant intervention' as at least three of the following six policies being used: deposit freezes/banking holidays, significant bank nationalizations, bank restructuring gross costs, extensive liquidity support, significant guarantees, and significant asset purchases (Laeven and Valencia, 2013, 229).
} 
similar approach of integrating the data sets to find a "partisan financial cycle" where right-leaning promarket governments implement policies that create economic booms, but also lead to crises. Voters then elect left-leaning governments to clean up afterwards. Crespo-Tenorio, Jensen and Rosas (2014), Chwieroth and Walter (2015), and Pepinsky (2012) use the data sets in their research on the political effects of crises. Crespo-Tenorio, Jensen and Rosas (2014) found that incumbents in countries with open capital markets are more likely to survive a crisis in power than incumbents in countries with closed capital markets. ${ }^{2}$

These data sets have a number of strong characteristics. They come from detailed comparative work that identifies some key features of crises, including estimated fiscal costs for a large number of countries. They also differentiate across different types of crises, such as exchange rate, inflation, and banking crises.

Yet, there are a number of problems with these indicators for studying political behaviour. Crucially, crises are identified post hoc by researchers who know what happened after the fact. Financial market stress that policymakers successfully address, thus preventing a major visible crisis, is not included. Similarly, stress that a government temporarily dampens through unsustainable policy measures, only to flare up later, is not recorded. This makes it difficult to study why and how politicians respond to financial market stress. The measures are dichotomous and so do not give any indication of how severe crises were. Crises rarely have uniform intensity over their course. Binary indicators do not allow us to understand intensity of a crisis over time. Having an annual dichotomous measure also means that measurement errors-incorrectly timing the start or end of a crisis-can strongly bias econometric model estimates.

Finally, there are some practical coding issues for scholars who use these measures. There are large inconsistencies between the timing of crises in the Laeven and Valencia (2013) and Reinhart and Rogoff (2009) data sets (Chaudron and de Haan, 2014). For example, Japan is labeled as having a crisis between 1997 and 2001 by the former, but between 1992 and 1997 by the latter. Furthermore, Gandrud and Hallerberg (2015) find that there are significant differences in crisis timing between different versions of the Laeven and Valencia (2013) data. Finally, while the measures use fairly precise definitions of when a crisis started, reasons for dating the end of a crisis are either unstated as in the case of Reinhart and Rogoff (2009) or are ad hoc. Laeven and Valencia (2013, footnote 19) determine that a crisis has concluded when real GDP and real credit growth are positive for two years, or five years have elapsed from the crisis start year.

Romer and Romer (2015) attempted to address many of the problems in the Reinhart and Rogoff (2009) and Laeven and Valencia (2013) data sets. To address the dichotomous variable concern, they use a 16 point scale of the cost of credit intermediation, which provides an indication of distress intensity. They code 24

\footnotetext{
${ }^{2}$ For an additional review of the literature see Gandrud and Hallerberg (2015), as well as tables 9 and 8 in the Online Appendix.
} 
countries using information from the OECD's semi-annual Economic Outlook reports from 1967 to 2007. Their continuous measure gives an indication of distress intensity. Relying on contemporaneous reports allows for the construction of a real-time measure of credit market distress and addresses potential problems with ex post coding. Researchers can examine policy choices that head off trouble or, conversely, prolong and perhaps worsen growing difficulties.

While their approach is an important improvement over previous work, it is limited in a number of ways. First, the time-intensive manner in which they collect data and their data sources means they are necessarily confined to the relatively small sample of OECD countries. Second, because their measure is laborious to create and update, even if there were a more encompassing corpus of texts than the OECD Economic Outlook, actually applying the method would be very costly. Third, relying on human coders may introduce well-known problems of inter-coder reliability and unreproducibility (Minhas, Ulfelder and Ward, 2015).

Another approach is to measure fragility and crisis nationally aggregated quantitative accounting data. The finance literature relies on a statistical quantity known as 'bank Z-Scores'. The concept was originally developed to assess firm solvency (see Roy, 1952). In the banking context, it is often used to measure national financial system fragility, which allows researchers to examine how banking system structures and policies affect the probability of financial system difficulties (e.g. Beck, De Jonghe and Schepens, 2013; Čihák and Hesse, 2010; Laeven and Levine, 2009; Uhde and Heimeshoff, 2009). Though there are various ways to calculate this measure (Lepetit and Strobel, 2013, 73), in general bank accounting information-assets, equity, and return on assets-is used to create an inverse measure of the probability that a country's banking system is 'insolvent'. Similarly, the CAMEL system uses accounting data to rate bank soundness. This looks specifically at a bank's capital adequacy, asset quality, management capacity, earnings, the liquidity of its assets, and its sensitivity to market risks (hence CAMELS). Andrianova et al. (2015) gathered individual bank data from the Bankscope service on these quantities for 128 countries, found annual national aggregates and released the components in a "database on financial fragility".

There have been a number of further innovations to the measurement of banking system stability using quantitative data. Though they make interesting contributions to measuring financial market stress, these indicators have not been used in applied research as frequently as Z-Scores or components of the CAMEL system. Building on Von Hagen and Ho (2007), Jing et al. (2015) develop an index of money market pressure based on changes in short-term interest rates and stocks of central bank reserves. Problematically for the study of policy responses, it assumes that central banks use the same reaction function to increase demand for liquidity. Rosas (2009) developed a dynamic latent trait model of banking system distress. His 
measure relies on nationally reported data to the IMF's International Financial Statistics (IFS). Copelovitch, Gandrud and Hallerberg (2015) show that reporting to the IFS is highly uneven across countries and time. They indicate that decisions to report data to the IFS could be endogenous to political events, complicating attempts to use IFS data to date crisis occurrence and severity. Further indicating the pervasiveness of the missingness problem with quantitative data, Andrianova et al. (2015) extensively discuss problems of missingness in their database on financial fragility and caution users of the database about the effects it might have on their analysis. Furthermore, as Kayser and Leininger (2015) show, people make decisions based on contemporaneously available information, but researchers attempting to understand their behaviour often use data that has been significantly updated after the fact. Using revised IFS data will give an inaccurate impression of the conditions that politicians believed they faced at the time. In addition, apart from ZScores-one version of which is available from the World Bank's Global Financial Development Database (World Bank, 2013)-and the database on financial fragility, many of these quantitative measures have not been made publicly available. ${ }^{3}$

\section{Creating the FinStress Index}

We overcome many of the problems noted above by using a new approach to estimate real-time perceptions of financial market stress through machine classification of Economist Intelligence Unit reports. ${ }^{4}$ In terms of conceptualization, this makes it most similar to the measures of banking system stability; that is, we focus on how this particular sector of the economy is performing.

In terms of the technical details, our method uses kernel principle component analysis (Scholkopf, Smola and Muller, 1998; Lodhi et al., 2002; Spirling, 2012) of monthly country reports from the Economist Intelligence Unit to create a monthly index for more than 180 countries from 2003 through $2011 .^{5}$

\footnotetext{
${ }^{3}$ Another approach to measuring crises, though not necessarily crises confined to the banking sector, is to classify periods below a pre-specified output gap as being in crisis. For example, in his examination of reforms in response to economic crises, including financial crises, Galasso determines a crisis to be when the output gap falls below the 90 percentile in his sample (2012, 154). Other work, notably Laeven and Valencia (2013) and Reinhart and Rogoff (2009) examine the output gap as a consequence of crisis, rather than the crisis itself.

${ }^{4}$ See http://www.eiu.com/. Accessed May 2015.

${ }^{5}$ Our approach is broadly similar to Minhas, Ulfelder and Ward (2015) who use a supervised machine learning approach called support vector machines and United States State Department Country Reports on Human Rights Practices to classify countries according to dichotomous regime types. Our work is distinct in that kernel PCA of EIU reports allows us to develop a continuous measure of perceived financial market stress. Also, their supervised learning approach assumes that countries have been well classified by previous indicators, which they use to train the model. As discussed above, we are not confident that this is the case for financial crisis. Therefore, we use the unsupervised kernel PCA approach to establish new estimates.
} 


\subsection{Why the EIU?}

The EIU compiles real-time, third-party assessments of financial market conditions reported monthly or, for a small subset of countries, quarterly. These reports contain perceptions of both present and future economic conditions. They are also an important channel through which this information is disseminated to public and private actors in many countries. Together, the reports create a large corpus, or more than 20,000 texts, of reports for more than 180 countries over the period 1997-2011. Although, due to issues of format comparability, we concentrate on data from 2003. In contrast, the OECD Economic Outlook used by Romer and Romer (2015) provides comparable reports for a very small number of wealthy countries on a bi-annual basis. As such, the EIU is preferable for creating a cross-country indicator of perceived financial market stress.

\subsection{Summarising financial market stress in the EIU}

Our aim is to create an index that classifies financial conditions on a continuous more-stressed/less-stressed spectrum for as many country-months as possible. Therefore, we need an efficient way to summarise the vast quantity of information in the EIU reports. To do this we first collected and processed the EIU texts. We then used kernel principal component analysis to place the texts onto a financial market stress spectrum. We rescaled the raw spectrum to ease interpretation.

\subsubsection{Text selection}

EIU reports assess many economic sectors within a country, not just the financial sector. So, our first step was to select the portions of the EIU texts that contained relevant information about countries' financial systems. We automatically collected and parsed the reports from their original HTML format. We then extracted the portions of the texts-headers and paragraphs-that contained at least one of a number of keywords concerning financial markets. ${ }^{6}$ Due to a significant change in the reports formatted in 2003, we selected only texts from 2003 in order to maintain comparability across the time-series. The texts from 2003 follow the same format and style and contain directly comparable assessments of economic conditions across the globe over a significant time span.

We then preprocessed the texts using standard techniques (see Grimmer and Stewart, 2013). ${ }^{7}$ This

\footnotetext{
${ }^{6}$ The keywords included: bail-out, bailout, balance sheet, balance-sheet, bank, banks, banking, credit, crunch, default, finance, financial, lend, loan, squeeze. These keywords are adapted from those used by Romer and Romer (2015) and are intended to select passages that discuss credit market conditions.

${ }^{7}$ All preprocessing was done using the tm package (Feinerer and Hornik, 2015) in R (R Core Team, 2015).
} 
involved removing common English words, such as 'was' and 'its'. The 'stopword' list we used to do this was from Dhillon and Modha (2001). We stemmed the words so that different variants of the same word are represented by a common 'stem'. This allowed us to work with a more manageable number of kernels. We removed extra white space between the words, as well as punctuation and numbers. Finally, we dropped texts that included very few words (less than six). In practice, including these texts would have prevented the estimation of the kernel PCA model.

\subsubsection{Kernel Principal Component Analysis}

Texts are frequently summarised using unordered 'bags-of-words' approaches that are analysed to find, for example, clusters of topics within speeches or clusters of speeches around topics (for a review see Grimmer and Stewart, 2013) are common results from these methods. We would like to preserve the order of the words in our texts and we would like to place the texts on a continuous scale that will be interpretable as a measure of perceived financial market stress. Many financial terms such as 'credit growth' and 'borrowing costs' have different interpretations depending on the adjectives that modify them; consider, for example, 'slowing credit growth' vs. 'expanding credit growth' or 'falling borrowing costs' vs. 'increasing borrowing costs'. Likewise, adjectives can have very different implications for describing market conditions depending on the nouns that they modify; For example, 'increasing' can indicate worsening conditions as in 'increasing non-performing loans' or improving conditions as in 'increasing lending'. A bags-of-words approach that treated each word as having meaning as an individual unit, rather than having meaning in ordered associations with other words, would not adequately capture commonly used and radically different meanings in the EIU documents.

In order to address these issues we use kernel principal component analysis. This method was developed by Scholkopf, Smola and Muller (1998) and Lodhi et al. (2002). Spirling (2012) introduced it into political science. He used it to summarise changing trends in treaties between the US government and Native American groups. Kernel PCA allows us to extract structure from our likely high-dimensional EIU corpus (Zhang, Wang and Ma, 2010, 6531-6537) while preserving word order.

Our unit of analysis is a sub-string kernel: a short sequence of letters ${ }^{8}$ that can be shared within and across words. Thus we can distinguish between two simple documents with the stemmed strings 'slow credit' and 'expand credit'. They share the five character kernels 'credi' and 'redit', but differ on 'slowc' and 'pandc', among others. Using Lodhi et al. (2002) we can summarise the similarity of these documents with

\footnotetext{
${ }^{8}$ The kernels are similar to n-grams though they do not need to be complete words. Following Spirling (2012), we used kernels with a length of five, i.e. those that are five letters long. See also Lodhi et al. (2002) who demonstrate that in English string lengths between four and seven are often optimal.
} 
the frequency distribution of five-length strings that they have in common-in this case one-standardized by document length. We can find these pairs for all of the documents in our corpus to create a kernel matrix. Finally, we can scale the documents using principal component analysis. ${ }^{9}$

\subsubsection{Dimensionality}

To determine the number of dimensions that best describe the data, we conducted a scree test, the results of which are shown in Figure 1. There is a clear 'elbow' in the plot at component two. This suggests that the first component explains the most variation in the data. In the rest of the article we focus on the first dimension as the main dimension summarizing financial market stress. We examined a number of the other dimensions. However, these noticeably did not closely correspond to our priors about financial market stress based on previous indicators. Below we detail how the first component corresponds to our expectations of a valid measure of perceived financial market stress.

It is important to note two simple transformations we conducted on the raw results to create the final FinStress Index. First, we rescaled the Index so that it would be between zero and one. ${ }^{10}$ This eases interpretation and comparability to other measures. Henceforth, we only use the rescaled version of the Index. Second, we smoothed the results by taking a two period-usually two months-moving average.

\section{Validation and Description}

The solid lines in figures 3 and 4 show the results of the kernel PCA analysis-the first principal component-for a wide selection of countries. What does this dimension actually represent? We took a number of approaches to answer this question. First, following Spirling (2012) we used a random forests "regression" (Breiman, 2001; Jones and Linder, 2015) as well as stem-component correlations to examine the relationships between word stems from the texts and the Index. Second, we compared the Index to prior information in previous indices.

\subsection{Random forests and correlations}

Spirling (2012, 88-90) demonstrated the usefulness of using random forests regressions to explore what principal components from textual analyses represent. To use this tool to explore our data, we first created a document-term frequency matrix from the stemmed documents. Effectively this is a $k \times s$ matrix recording

\footnotetext{
${ }^{9}$ We conducted kernel PCA with the kpca function from the R package kernlab (Karatzoglou et al., 2004).

${ }^{10} \frac{x-\min (\boldsymbol{X})}{\max (\boldsymbol{X})-\min (\boldsymbol{X})}$, where $\boldsymbol{X}$ is the vector of the first principal component and $x$ is an individual value from this vector.
} 
Figure 1: Assessing Model Fit: Eigenvalues for Kernel Principal Components

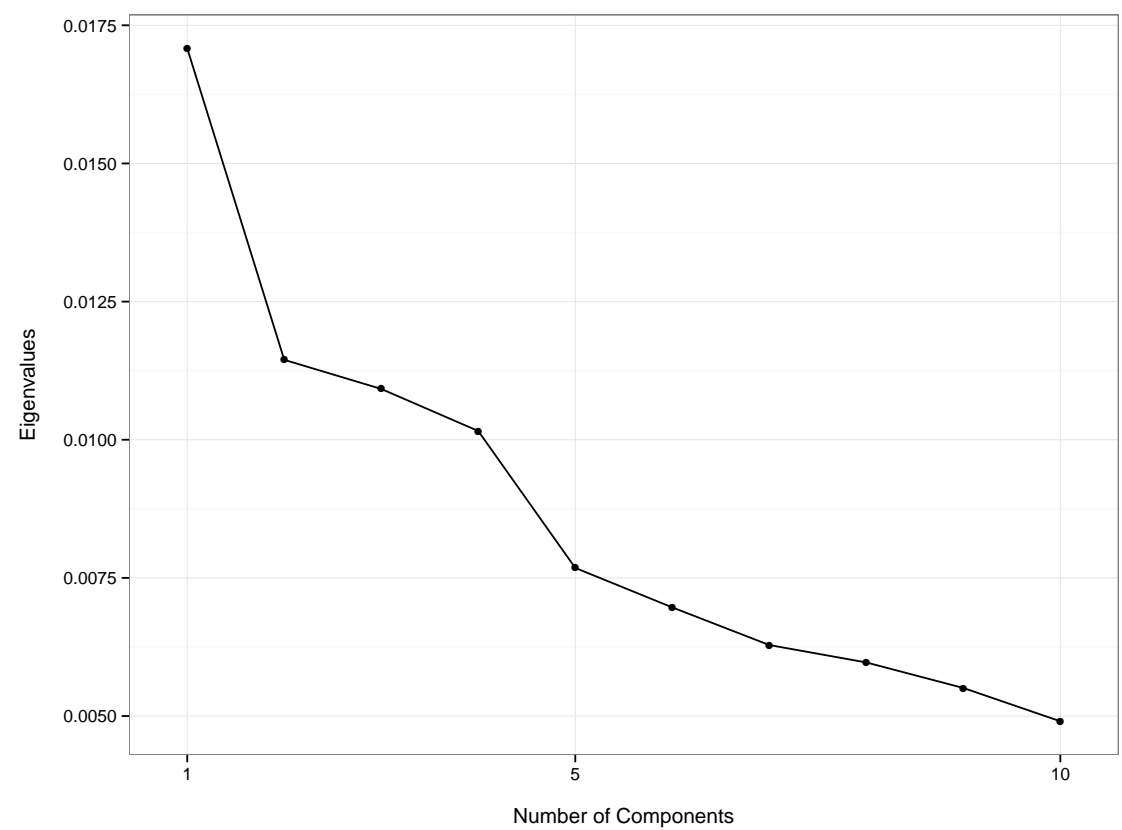

the frequency of each stem in $\boldsymbol{S}$ for each document in $\boldsymbol{K}$. The document-term matrix clearly does not preserve word order, so should only be thought of as one of a number of ways of assessing validity. We removed sparse terms, i.e. kept only stems that were found in 90 percent of the documents. Random forests regressions, as opposed to ordinary least squares regressions, are useful for exploring this data's associations with the estimated principal components because it can handle many variables-in this case 1,116 stems-relative to the number of documents-12,377.

We focus on estimated variable importance from this analysis. ${ }^{11}$ Variable importance in this context functions as a measure of how well the frequency of a given stem in a text allows the model to predict the FinStress score for that text. Key results are shown in Figure 2.

Unsurprisingly, a number of the stems with the largest variable importance are 'bank', 'financi', and 'loan'. Terms with these stems were used to select the texts. The prevalence of these terms and others that are clearly related to the financial sector, such as 'interest', 'rate', and 'fund', indicate that FinStress is indeed about financial sector conditions and not some other topic. Words relating to the direction of financial conditions are important including, 'growth' and 'rise'. We can see that words relating to the the macro-

\footnotetext{
${ }^{11}$ We conducted the random forests regressions using the rfsrc function from the randomForestSRC R package (Ishwaran and Kogalur, 2015).
} 
Figure 2: 40 Stems Estimated to be the Most Important for Predicting EIU Perception of Financial Market Stress Index

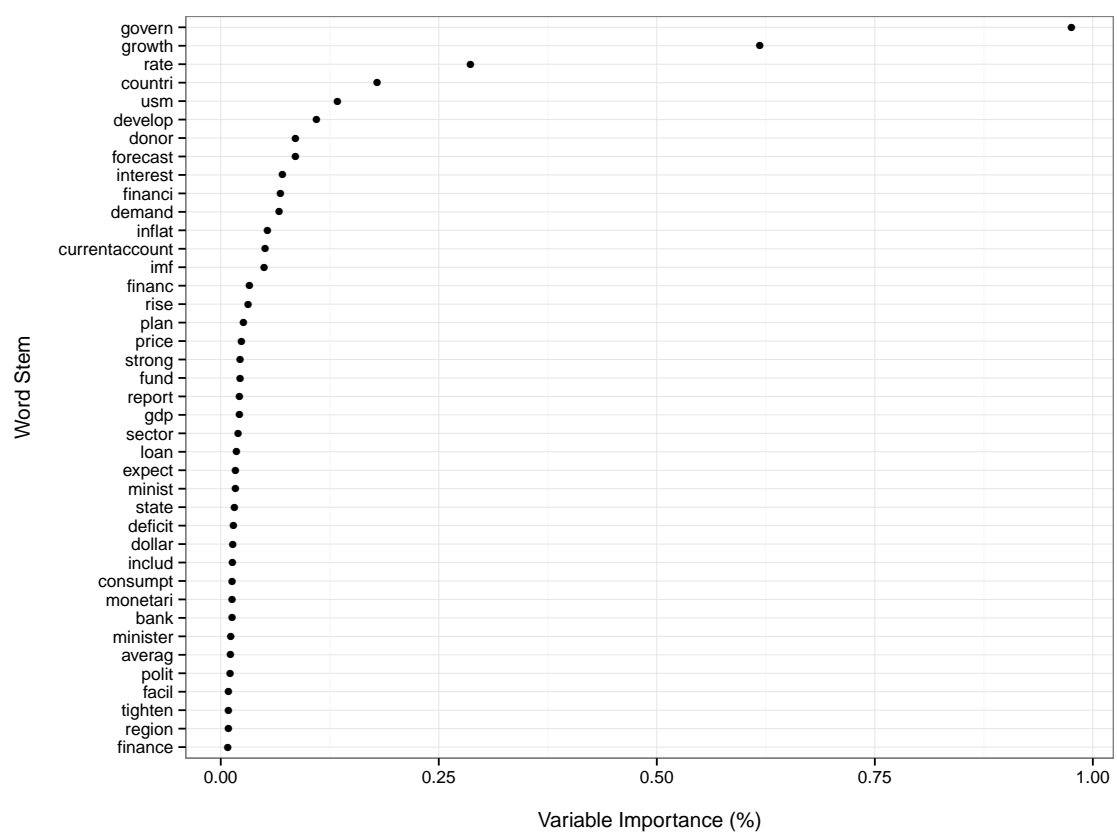

political economic environment of finance are also important, including 'govern', 'imf', and 'currentaccount'.

Table 2 shows a selection of correlations to help us get a sense of the general directions of the relationships between the stems and the Index not provided by the random forest variable importance estimates. We can see that a number of terms related to debt, financial assistance, the International Monetary Fund, and aid are positively related to FinStress. This suggests that the positive direction of the scale is in fact capturing periods where policy-makers perceive higher financial market stress. Words that are generally about positive credit conditions, such as 'growth', 'surplus', and 'boom' are negatively associated with the Index. This suggests that the lower end of the scale indeed indicates more positive financial market conditions. Finally, we can see that adjectives that have seemingly opposite meanings-'stronger' and 'weaker'-are both negatively associated with the Index. Such a finding indicates that a kernel PCA approach is useful compared to context-less bag-of-words approaches.

\subsection{Qualitatively examining texts}

While they allow us summarise our more than 12,000 documents, random forest regressions and correlations only allow us to examine how individual words are related to the FinStress estimates. We also examined the 
Table 2: Selection of Word Stems and Correlations with FinStress

\begin{tabular}{lr}
\hline Stems & Correlations \\
\hline imf & 0.34 \\
assist & 0.34 \\
aid & 0.28 \\
debt & 0.24 \\
paid & 0.19 \\
strain & 0.09 \\
boom & -0.14 \\
surplus & -0.14 \\
rise & -0.14 \\
weaker & -0.16 \\
stronger & -0.17 \\
growth & -0.28 \\
\hline
\end{tabular}

full text of a selection of documents to get a more complete picture of what types of documents constitute high and low FinStress scores.

Tables 3 and 4 provide snippets of texts with country maximum and minimum FinStress scores. We selected the countries such that we have a range of maximum scores. Brazil had a relatively low maximum FinStress score in the sample- 0.58 in 2003. The text this score is from reflects this relatively middling score. It highlights that lending to industry has increased, while "consumer credit has been flat" and consumer prices are increasing. Latvia had a higher maximum FinStress score-0.65 in 2009-and the text this score is generated from clearly describes a more troubled financial sector. The economy is noted to be "slowing sharply" leading households and companies to focus on reducing debts, and foreign banks reducing their exposure to the country. Ireland had a relatively high maximum FinStress score-0.78 in 2011. The text this score is estimated from describes a highly troubled banking system that is going through a painful restructuring process is reducing the supply of credit to the economy.

The texts that created country-minimum FinStress scores-shown in Table 4-describe "confidence in financial markets" in Brazil (2005), a "lending boom" in Latvia (2006), and "strong business confidence" in Ireland (2007). Importantly, in the Latvian and Irish cases the texts are not without clear concerns that the boom may not continue in the future. So while low FinStress scores appear to be reflecting financial markets with strong credit provision embedded in these texts is a concern that the boom may be peaking. This is an important finding to keep in mind when interpreting the substantive meaning of low FinStress scores. 
Table 3: Portions of Texts EIU Reports with Country-Maximum FinStress values (selected countries)

\begin{tabular}{|c|c|c|c|}
\hline Country & Month-Year & FinStress & Text Selection \\
\hline Brazil & August 2003 & 0.58 & $\begin{array}{l}\text { While domestic lending to industry picked up in the second half } \\
\text { of the year, consumer credit has been flat ...the effects of ex- } \\
\text { change rate depreciation on input costs in } 2002 \text { is still being felt } \\
\text { in continued pressure on consumer prices in early } 2003 \text {, requiring } \\
\text { stringent monetary policy to suppress inflation. }\end{array}$ \\
\hline Latvia & June 2009 & 0.65 & $\begin{array}{l}\text { The economy is slowing sharply, and real GDP contracted by } 18 \% \\
\text { in the first quarter of } 2009 \ldots \text { In the current economic climate } \\
\text { most Latvian households and companies will concentrate on re- } \\
\text { ducing their debts; foreign banks operating in Latvia are also } \\
\text { trying to reduce their exposure to Latvia by lending less. }\end{array}$ \\
\hline Ireland & April 2011 & 0.78 & $\begin{array}{l}\text { Irish households are highly indebted. Private consumption will } \\
\text { therefore be constrained as households rebalance their balance } \\
\text { sheets and as credit conditions remain tight in } 2011-13 \text {. Invest- } \\
\text { ment will continue to shrink in } 2012 \text { as the collapse of the construc- } \\
\text { tion industry maintains momentum ... [the] most recent stress } \\
\text { tests reveal the complete failure of earlier attempts to assess the } \\
\text { impairment of the banks' balance sheets. Of particular note is the } \\
\text { fact that no serious provision had previously been made for losses } \\
\text { on the banks' mortgage lending, despite a massive collapse in the } \\
\text { residential property market that has been ongoing for some years. }\end{array}$ \\
\hline
\end{tabular}


Table 4: Portions of Texts EIU Reports with Country-Minimum FinStress Values (selected countries)

\begin{tabular}{|c|c|c|c|}
\hline Country & Month-Year & FinStress & Text Selection \\
\hline Brazil & August 2005 & 0.05 & $\begin{array}{l}\text { By continuing to meet the target for the primary fiscal surplus de- } \\
\text { spite strong political pressure to increase spending on social pro- } \\
\text { grammes, and by increasing the benchmark Selic overnight rate } \\
\text { until inflation began to subside in June, the government has con- } \\
\text { firmed its cautious stance. Apart from keeping a rein on inflation, } \\
\text { this has helped to maintain confidence in the financial markets. }\end{array}$ \\
\hline Latvia & March 2006 & 0.18 & $\begin{array}{l}\text { The BoL [Bank of Latvia] has tried to curb the current lending } \\
\text { boom by raising the mandatory reserve requirements for banks } \\
\text { from } 4 \% \text { to } 8 \% \text { in 2005, in two steps. Further increases seem } \\
\text { unlikely, as Latvian customers could be served from other EU } \\
\text { countries if the costs of banking in Latvia become excessive. }\end{array}$ \\
\hline Ireland & January 2007 & 0.06 & $\begin{array}{l}\text { Private consumption will be fuelled in } 2007 \text { by strong employment } \\
\text { growth, solid real wage increases, tax cuts, lower inflation and } \\
\text { the maturing of a generous government-financed savings scheme } \\
\ldots \text {.. Strong business confidence and a still-booming construction } \\
\text { sector will bolster growth, but an anticipated cooling of the hous- } \\
\text { ing market will account for the deceleration over the outlook } \\
\text { period. }\end{array}$ \\
\hline
\end{tabular}




\subsection{Compared to other crisis measures}

How does the Index compare to previous ways of measuring and timing financial market stress and crisis? We first compare the FinStress Index to the dichotomous measures in Reinhart and Rogoff (2009) and Laeven and Valencia (2013), as well as Romer and Romer's (2015) continuous measure. Based on our review of the data sets, we have several expectations we evaluate.

We anticipate that the Reinhart and Rogoff and Laeven and Valencia measures should be positively correlated with FinStress, they are both sensitive to extreme stress, particularly if there is a large government response. At the same time, because of the other issues we find present in these variables, the correlation should be fairly weak. More important than the not particularly informative simple correlation between our continuous measure and the rare events binary variables is that we expect the binary measures to miss the build-up to crises, as well as cases where there is a build-up in pressure but the full-blown crisis does not develop. Using data transformed in the way discussed below, FinStress and Laeven and Valencia's banking crisis measure do have a positive correlation coefficient as expected and, as expected, it is weak at 0.088 . Similarly, FinStress and Reinhart and Rogoff's measure have a correlation coefficient of 0.087. Romer and Romer's more similar continuous and contemporaneously text based index is more strongly correlated with FinStress at 0.248 . Note that all correlations are statistically significant at the $5 \%$ level. $^{12}$

To follow up on the expectation that our measure is capturing the same concept, but with more nuance especially in magnitude and over time, figures 3 and 4 plot the four measures for a wide selection of countries. $^{13}$ The solid lines in figures 3 and 4 show the FinStress Index. The dashed lines show Romer and Romer's (rescaled) measure. The shaded boxes show the periods where Laeven and Valencia (2013) and Reinhart and Rogoff (2009) classify the existence of a banking crisis. Laeven and Valencia (2013) identify eight "borderline" crises in this period, in that the countries almost meet their systemic banking crisis definition because they only used two rather than three policy responses. ${ }^{15}$ Some of these borderline cases are shown in the figures 3 and 4 .

\footnotetext{
${ }^{12}$ We use Table 1 in Romer and Romer (2015) to recreate their data set. The Laeven and Valencia's data is from: https:// www. imf.org/external/pubs/cat/longres. aspx?sk=26015.0. Accessed May 2015. Reinhart and Rogoff's data was downloaded from: http://www.carmenreinhart.com/data/browse-by-topic/topics/7/. Accessed May 2015.

${ }^{13}$ There are some limitations in comparability due to the different periods of coverage of the different indices. Romer and Romer (2015) in particular largely do not include the most recent crisis in their sample as they did not collect data past 2007. We also had to make a number of transformations and assumptions to be able to compare directly the different data sets. First, the Laeven and Valencia and Reinhart and Rogoff data are recorded at yearly intervals. We assume that the crisis start and end dates they referred to were in the middle of the year, i.e. June. ${ }^{14}$ Second, we rescale Romer and Romer's 16 -point scale (in effect 14-points because they do not classify any country-quarter in their sample as being at the upper two positions on their scale) to be between 0 and 1 using the same method as discussed above for FinStress. Finally, it should be noted that Romer and Romer (2015) only cover a selection of OECD countries and Reinhart and Rogoff (2009) only cover 70 countries and their data has been updated least recently.

${ }^{15}$ The cases are: France, Hungary, Italy, Portugal, Russia, Slovenia, Sweden, and Switzerland.
} 
In many cases-conditional on the coverage of each data series-the indices do substantively overlap. Comparisons with Romer and Romer (2015) are limited, but we can see that, where comparable time series are available, there are cases where FinStress and their index are similar: for example, both indices increase in the US from early 2007. A notable difference is how Romer and Romer classify Japan as being without stress from mid-2005, while FinStress remains relatively high, especially compared to many other economically developed countries at that time. While both indices classify Iceland as being under stress in the late 2000s, the timing is different. Romer and Romer classify Iceland as in stress ${ }^{16}$ in 2006-2007. This is earlier than not only a marked increase in the FinStress Index, but also Reinhart and Rogoff and Laeven and Valencia's timing.

Reinhart and Rogoff (2009) sometimes start dating a crisis before Laeven and Valencia (2013)-notable cases include Iceland and Ireland. This could reflect the slightly different definitions that they use. As summarised in Table 1, Reinhart and Rogoff (2009) date crises from when bank runs occur. Laeven and Valencia (2013) begin the crisis clock when there is not only significant financial system distress, but also when the government follows the distress with a policy response.

We would like to point out that these findings have theoretical relevance. We indicate that high levels of stress should appear where there is crisis in the dichotomous codes, but the reverse may not be true-the dichotomous indices may miss a building crisis. This means that Laeven and Valencia and Reinhart and Rogoff should have more Type II errors-there are signs of a crisis but they miss them. The Laeven and Valencia coding is stricter in that countries have to both experience distress and have a policy response to it, so the associated FinStress levels should be higher. Finding evidence supporting these expectations would reinforce our arguments about the problems with their measures.

We do find that the mean FinStress level during periods that Laeven and Valencia classify as crises-i.e., financial market stress reached the point where politicians responded using a pre-specified set of policiesis higher than non-crisis periods, 0.55 and 0.51 , respectively. This is a statistically significant difference using one-sided and two-sided t-tests. Though developing countries tend to have higher FinStress scores, countries in Laeven and Valencia defined crises in both groups on average have FinStress scores around 0.55, while those not in crises have lower scores. Please see the Online Appendix for a discussion of the distributions of FinStress scores in developed and developing economies. Overall, developing countries have more stressed financial markets, which does not always lead the government to take policy measures that Laeven and Valencia are looking for. The fact that the mean FinStress is higher during periods that Laeven

\footnotetext{
${ }^{16}$ They classify Iceland as being in a "minor crisis" in the second half of 2006 and a "credit disruption" in the first half of 2007.
} 
and Valencia classify as crises, but not dramatically, supports the proposition that they miss considerable periods of budding and high stress and perhaps suffer from more Type II errors.

We can use FinStress to follow the progression of crisis intensity over time. Laeven and Valencia (2013, 227) comment that part of the problem with dating financial crises is that each develops differently:

Some crises evolve gradually, gaining speed as the ripple effects from a seemingly small shock propagate forward in time ... other episodes happen more abruptly and are often the result of sudden stops.

FinStress' real-time and relatively granular nature allows us to distinguish these types of crises. This has relevance when thinking about how crises develop over time. For example, we can see in Figure 4 that financial market difficulties in the United States built over a long period of time, with a few spikes during notable banking difficulties, e.g. Lehman Brothers' collapse. Conversely, countries such as Germany, Hungary, and Iceland clearly have much more sudden periods of perceived financial distress. The Greek case presents an interesting additional trajectory. There is a notable spike in Greek financial stress in 2008-when both Reinhart and Rogoff (2009) and Laeven and Valencia (2013) determine a crisis had started. This is then followed by a stable period, followed by a sudden uptick in 2010, which was when a possible government default severely threatened the banking system.

Kazakhstan is notable for another trajectory: a very rapid stress onset and just as rapid dissipation (see Figure 4). In late 2009 there was a prominent spike in perceptions of financial market stress directly related to a credit crunch that hit the country's banking sector as an after shock of the Global Financial Crisis. According to an IMF assessment, ${ }^{17}$ a large and quick policy response-facilitated by the sizable National Oil Fund-within a few months returned the country's FinStress score to almost its previous trend level.

FinStress allows us to explore why different crises follow different trajectories over a series of months. An annual binary definition of crises does not allow us to capture these changes over time.

We can use FinStress to identify periods where financial market conditions were perceived to be worsening, though for whatever reason these perceptions changed before other measures would record a financial crisis. Australia, Brazil, and the Czech Republic, among others, in late-2008/2009 are notable examples. They all have clear spikes in perceptions of stress shortly after Lehman Brothers collapsed in the US. Fairly quickly thereafter, their FinStress scores returned to previous levels. Laeven and Valencia and Reinhart and Rogoff do not distinguish these periods from those with little financial market stress. While there were not wide

\footnotetext{
${ }^{17}$ See: http://www.imf.org/external/pubs/ft/survey/so/2010/car081710a.htm. Accessed November 2015
} 
spread bank failures in these cases, the fact that they are treated as the same as placid periods by the binary measures makes it impossible to study how policy choices may have contributed to heading off worse stress.

The advantages of FinStress are also apparent for timing the end of heightened financial market distress. This is a particularly difficult issue for the established binary indicators. Crisis onset is typically well defined by these measures, but they rarely have a clear or non-ad hoc way of determining when a crisis has ended. Though we are limited by the time period coverage of the EIU texts we have at our disposal, it is clear that some countries, notably the Netherlands, Switzerland, the United Kingdom, and the United States, were perceived to be having improved financial market conditions from about 2010. Other countries, particularly Eurozone countries in Western and Southern Europe plateaued at a high level through the end of 2011, a period that corresponds with the Eurozone crisis. Laeven and Valencia's measure uses an ad hoc definition of crisis termination (see above) and so simply describes these entire periods as crises with equal intensity. Not only does FinStress allow us to more accurately date when conditions were seen to have improved, but it also allows us to study the trajectory of these improvements.

Overall, the similarities between FinStress scores and other measures of crises suggest that the Index does capture financial market stress in that higher FinStress values are indicative of higher levels of perceived financial market stress. At the same time, the differences between the measures indicate that FinStress sheds unique light on processes not captured well by previous indices.

\subsection{Comparison to accounting measures of banking system fragility}

CAMELS How does FinStress compare to the components of the CAMELS system of bank soundness? Examining these relationships will give us a better sense of FinStress' substantive meaning. We again used annual summarises of the FinStress Index to compare it to annual national aggregates of the CAMEL variables in Andrianova et al. (2015). Figure 5 shows the relationships between FinStress and these variables. FinStress is statistically significantly associated with six of the seven CAMELS variables at the $5 \%$ level. ${ }^{18}$ FinStress is very strongly associated with three of the CAMEL variables in that there is a correlation coefficient greater than 0.25 or less than -0.25 . These variables are impaired assets to gross loans, net loans to total loans, and liquid assets to total assets. See Figure 9 in the Online Appendix for a full correlation matrix.

FinStress is strongly positively associated with impaired assets. ${ }^{19}$ Impaired assets are otherwise often known as non-performing loans. Banks are solvent when their assets (e.g. loans and the income they

\footnotetext{
${ }^{18}$ It is not significantly associated with Return on Average Assets. Please see the correlation table in the Appendix for details.

${ }^{19}$ The log of impaired assets is associated with FinStress with a correlation coefficient of 0.43 , significant at all standard levels
} 
Figure 3: Comparing Perceptions of Financial Market Conditions to Laeven and Valencia (2013) and Reinhart and Rogoff (2009) (1)
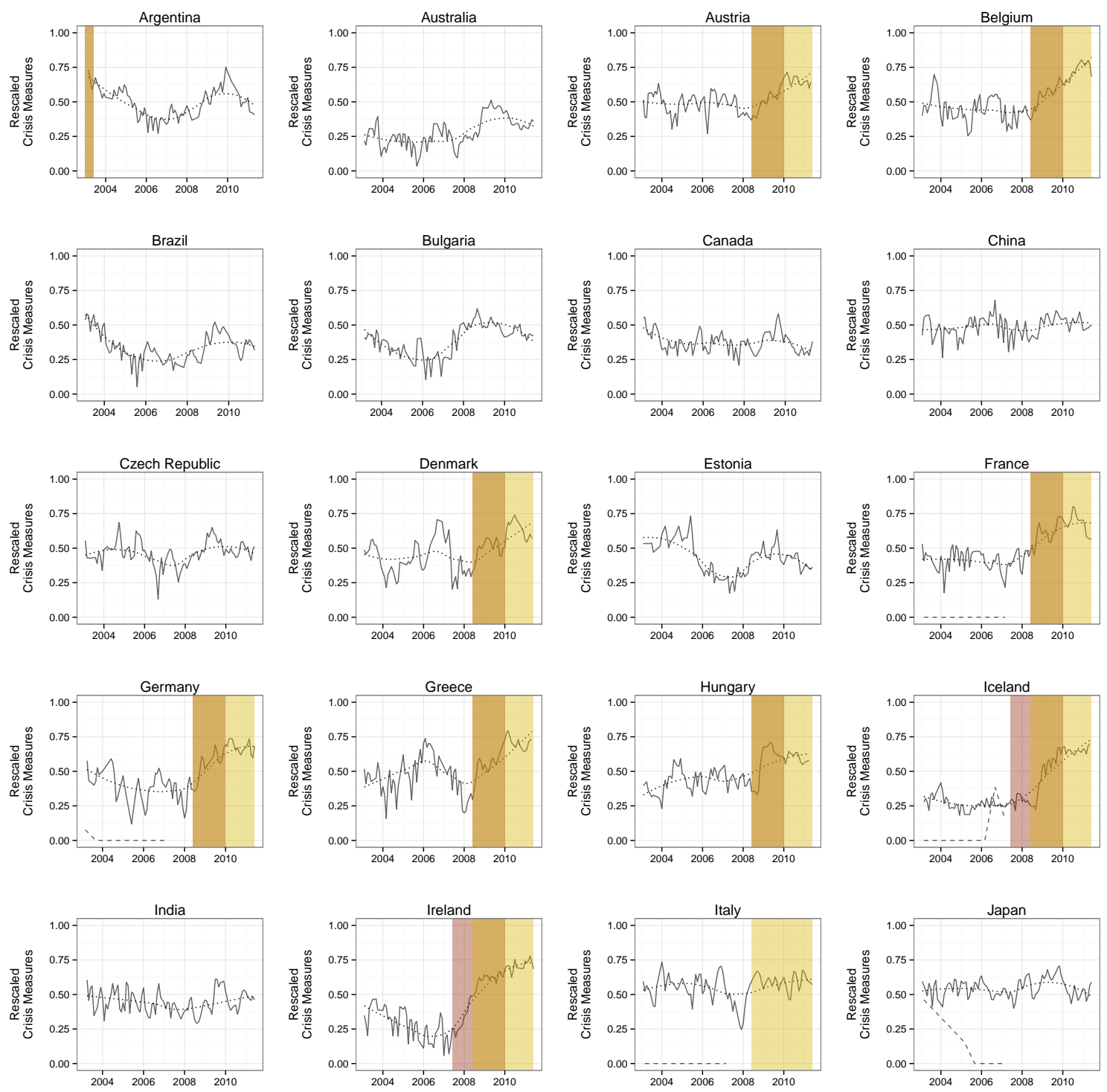

Solid lines show the FinStress Index. Dotted lines represent a loess smoother of these series.

Yellow shaded areas indicate periods that Laeven and Valencia (2013) classify as systemic banking crises. Note that crises are automatically terminated at the end of 2011 due to the series not extending beyond this point, not necessarily because the crisis finished.

Red shaded areas indicate periods that Reinhart and Rogoff (2009) classify as banking crises. Note that crises are automatically terminated at the end of 2009 due to the series not extending beyond this point, not necessarily because the crisis finished.

Orange areas indicate periods where a crisis is recorded for both measures. 
Figure 4: Comparing Perceptions of Financial Market Conditions to Laeven and Valencia (2013) and Reinhart and Rogoff (2009) (2)
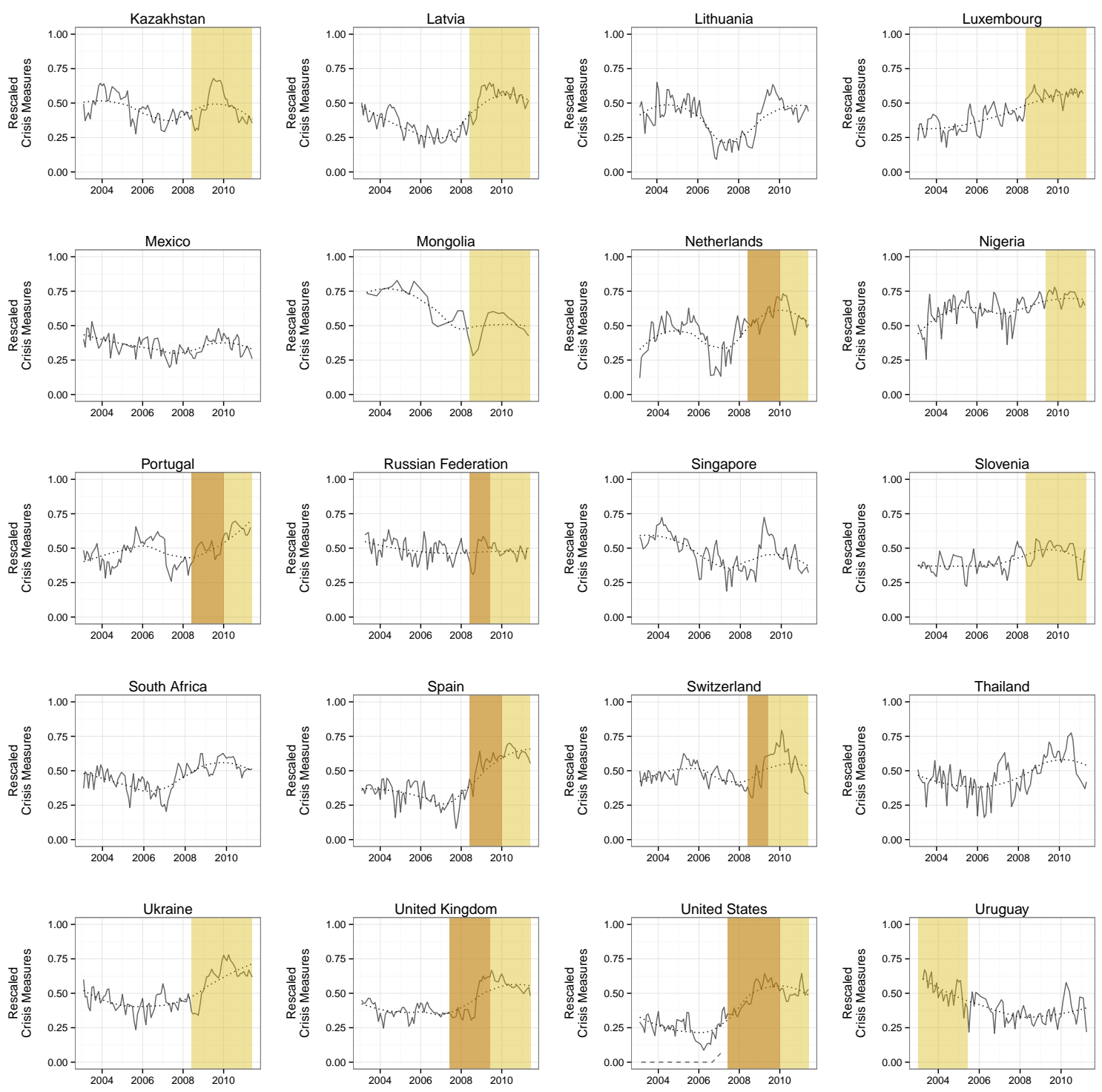
Figure 5: Comparing Perceptions of Financial Market Conditions with Components of the CAMEL System from Andrianova et al. (2015)
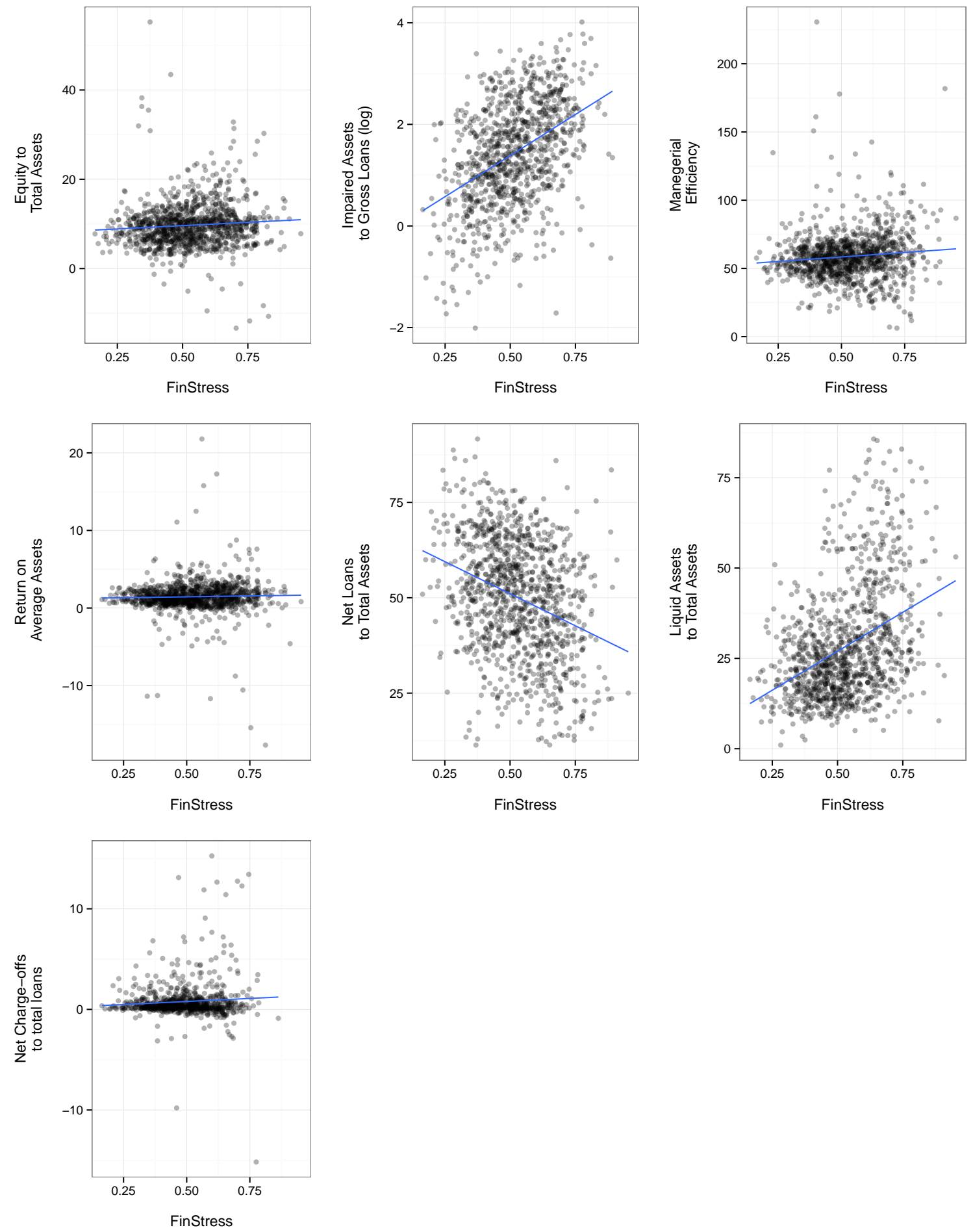
generate) can cover their liabilities (e.g. deposit withdrawals). Impaired assets greatly threaten banks' ability to meet their obligations and so threaten their solvency. As such, it seems as though FinStress is closely related to bank balance sheet health. ${ }^{20}$

Initially, it may seem strange that FinStress is positively associated with liquid (e.g. cash) asset ratios. Banks with more liquid assets are less likely to become insolvent because they can use these assets to meet their liabilities. However, high liquid asset ratios can be a manifestation of a stressed financial system as banks create large liquid asset stockpiles when they are reluctant to lend-take on less liquid assets. This behaviour restricts credit to the wider financial system and economy. Following the Lehman Brothers collapse in 2008 an extreme version of this occurred, becoming known as a credit crunch. Andrianova et al. (2014) find that African banks have very high liquid asset ratios because lending risks are high and banks are reluctant to make new loans. To a large extent net loans and liquid assets are inversely related. As such we find a negative relationship between net loans and FinStress-banks in countries with higher FinStress scores are making fewer loans and instead are hording liquid assets.

Comparing FinStress to accounting measures of bank stress allows us to gain greater insight into its qualitative interpretation. Higher FinStress scores are associated with banking systems with poor quality loans and limited credit creation.

Z-Scores How does FinStress compare to the widely used Z-Score measure of banking system fragility? Though the two quantities measure different phenomena-perceptions for the former and bank accounting relationships for the latter-both potentially provide indications of stress. As was the case for the dichotomous measures of financial crises, we would expect them to be positively correlated with one another. Another interesting question would be whether one would precede the other. Does weakness in accounting quantities proceed perceived stress?

To explore these possibilities, we compare FinStress to the easily accessible Bank Z-Score measure compiled from Bankscope data in the World Bank's Global Financial Development Database (GFDD) project (World Bank, 2013). ${ }^{21}$ The measure is interpretable as the inverse of the upper bound of the probability of

\footnotetext{
${ }^{20}$ Note the outliers in the middle-top panel of Figure 5 that seemingly have both high stress and very low impaired loan levels. The countries in with (log) impaired loans less than 0 and FinStress greater than 0.6 are: the Democratic Republic of Congo (2008, 2010), Cote d'Ivoire (2011), Estonia (2004), Guinea-Bissau (2011), Kyrgyzstan (2007, 2011), Seychelles (2006, 2007), Sudan (2008), and Uzbekistan (2004). These countries also have considerable missingness in their Bankscope data in that many banks in these countries do not report data. It is likely that either the low impaired loan scores are based on reporting by only less troubled banks or there is inaccurate reporting. In these cases it is likely that FinStress is a better measure of banking system health.

${ }^{21}$ Indicator ID: GFDD.SI.01. Accessed June 2015.
} 
the banking system's insolvency. ${ }^{22}$ Figure 6 shows a comparison of the two measures for selected countries. Note that to ease visual comparability we rescaled the Z-Scores to be within zero and one as before, and reversed the scale so that larger values indicate a higher probability of banking system insolvency. ${ }^{23}$ Finally, we converted FinStress to yearly averages for comparability.

There does not appear to be much of a relationship between Z-Scores and FinStress. The rescaled World Bank Z-Scores are positively correlated with FinStress, but this is not significant at the $10 \%$ level. ${ }^{24}$ Interestingly, the World Bank's Z-Scores do not vary significantly within countries over time, especially compared to FinStress. There is little difference between Z-Scores for countries during periods of heightened financial stress (however measured) and more stable times. Thus Z-Scores, at least those provided by the World Bank, are not a useful indicator of financial crisis states. Z-Scores do not appear to predict perceptions of financial market stress. In a simple partial correction linear regression that had FinStress as the dependent variable and included lagged FinStress, lagged Z-Scores, and country fixed-effects, Z-Scores were not statistically significantly associated with perceptions of financial market stress (see the Online Appendix).

The simplicity with which Z-Scores can be calculated with readily available data likely contributes to their wide use in the literature, especially relative to other quantitative measures of financial system fragility that are often difficult to obtain. However, it is clear that Z-Scores-at least the version available through the World Bank's GFDD-are a sub-optimal cross-time measure of financial market stress. It is beyond the scope of our article to determine the source of the measure's peculiar characteristics, but they are important to note here: the indicator has weak time-variance, it does not distinguish between periods of significant known financial market stress and less stressful times, and it does not help us predict perceived financial market stress. FinStress, in contrast, is much notably time-variant in ways that correspond closely to prior information on financial market stress.

\footnotetext{
${ }^{22}$ Formally: $\frac{\mathrm{ROA}_{t}+\frac{\text { equity }_{t}}{\text { assets }_{t}}}{\sigma_{\mathrm{ROA}}}$. ROA is return on equity. $\sigma_{\mathrm{ROA}}$ is presumably for the entire period for which data is available, though the World Bank's documentation does not explicitly specify this. It is common in other work for the $\sigma_{\mathrm{ROA}}$ to be based on a three year rolling window (Beck, De Jonghe and Schepens, 2013, 225). All quantities are country aggregates.

${ }^{23}$ It is common to log-transform the Z-Scores (Beck, De Jonghe and Schepens, 2013, 225). However, it is unclear how previous work has done this as there are negative values in the Z-score that would create undefined values when logged.

${ }^{24}$ We also examined an alternative data source compiled by Andrianova et al. (2015), which transformed Bankscope data as well. In this case there was a weak positive association significant at the $5 \%$ level. However, again there was little cross-time variation in the Z-Score.
} 
Figure 6: Annual Mean FinStress Compared to Country-level Z-Scores (rescaled)

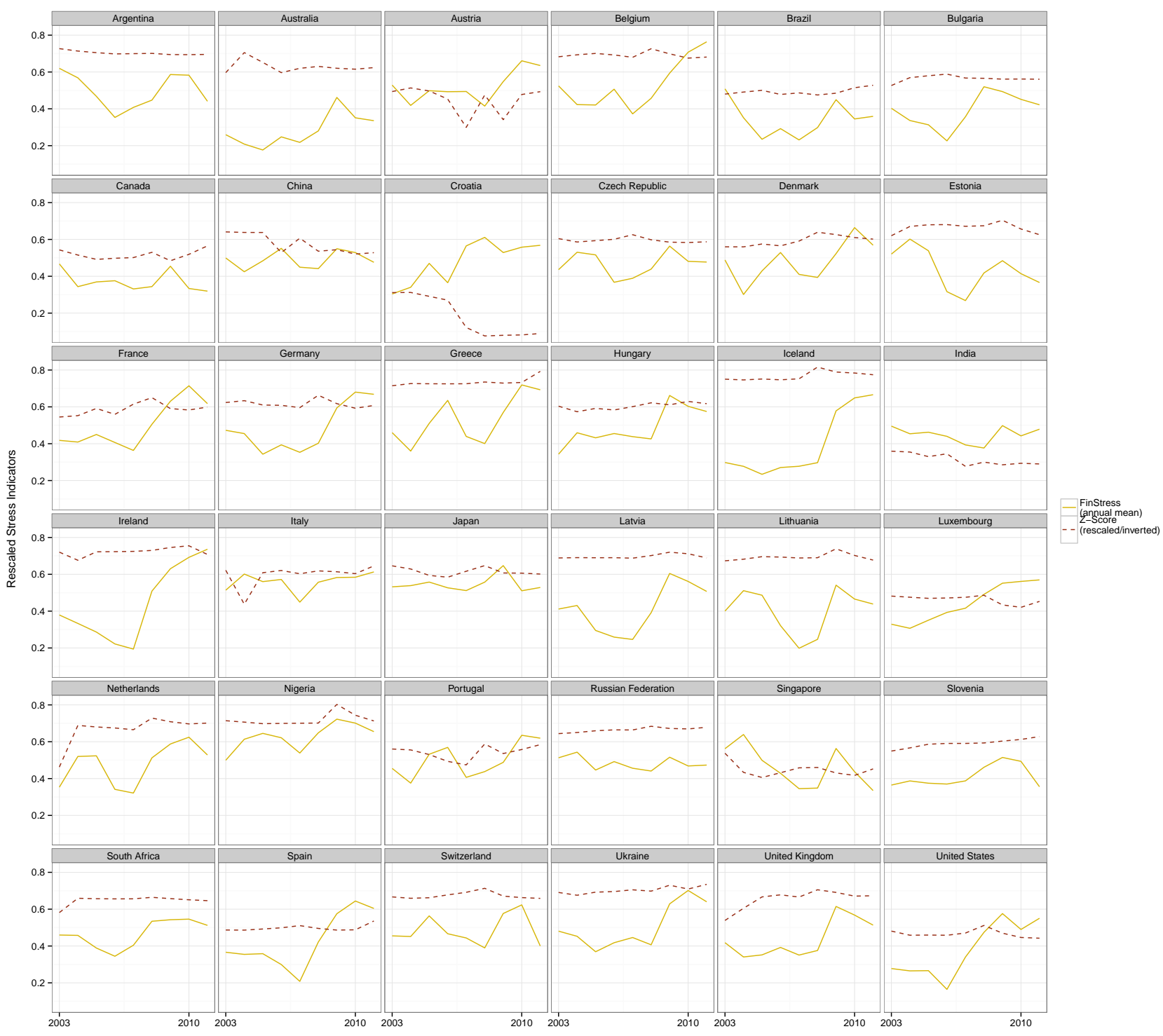




\section{Summarising FinStress Changes}

So far we have largely examined FinStress levels. Now we turn to examining FinStress level changes. To do this we use a nonparametric drift-diffusion-jump model (DDJ, Carpenter and Brock, 2011; Dakos et al., 2012). This approach allows us to draw general conclusions about how perceptions of financial market stress change in more demanding and less demanding times.

DDJ models allow us to approximate processes of change in a time series without needing to make explicit assumptions about the underlying process that creates these changes. ${ }^{25}$ Drift is a measure of the local rate of change. Diffusion codes small changes that happen at each time increment. Jumps are larger shocks that occur intermittently and are uncorrelated in time. The approach we take to estimating the DDJ model is from Carpenter and Brock (2011). ${ }^{26}$

We would expect that jumps would be more common in countries' FinStress scores during crisis periods, because there would be large moves in the Index. To test this we first graphically compared the distributions of jump and diffusion parameters across what Laeven and Valencia ${ }^{27}$ classify as crisis and non-crisis periods. Figure 7 shows these densities. We have also included a measure of total variance, which is a summary of both jump and diffusion parameters.

We can see that the distribution of estimated jump parameters in 'non-crisis' periods is shifted upward from the distribution of jump parameters in 'crisis' periods. Conversely, the distribution of diffusion parameters in crisis periods is shifted upward from non-crisis periods. Finally, the distribution of total variance in crisis periods is lower than non-crisis periods. We found these distributions to be statistically significantly different in the described direction at all conventional levels using one-sided Kolmogorov-Smirnov tests. ${ }^{28}$

This is a counter-intuitive result considering our prior expectations. How can we make sense of it? It is useful to refer back to figures 3 and 4 . Notice that some of the periods that are classified across measures as a crisis do indeed begin with a jump. Iceland and Ireland in 2008 are particularly illustrative of this. What happens after the jump is interesting. Before crisis periods there are sometimes large swings in both positive and negative directions. In crisis periods-especially at the point that there are large policy responses, a key

\footnotetext{
${ }^{25}$ It should be stressed that unlike in other applications of DDJ models, such as in ecology and related work in finance (Kou, 2008), where they are used to predict future states, we employ this statistical approach exclusively to summarise changes and elucidate patterns in observed data.

${ }^{26}$ The model approximates the unknown process generating FinStress scores: $d x_{t}=f\left(x_{t}, \theta_{t}\right) d t+g\left(x_{t}, \theta_{t}\right) d w+d J_{t} . d x_{t}$ is the change in the FinStress score $x$ for a country at time $t$. $\theta_{t}$ is a critical transition parameter. The drift function is given by $f\left(x_{t} \theta_{t}\right) d t$. The diffusion function is given by $g\left(x_{t} \theta_{t}\right) d w . J$ is a jump process. Please see Dakos et al. (2012, 7) for further details. We estimated the model using the ddjnonparam_ews function from the earlywarnings $\mathrm{R}$ package (Dakos and Lahti, 2013). Note that we estimated the parameters for each country's time series separately.

${ }^{27}$ Despite the previously discussed shortcomings, they are the most recently updated and comprehensive binary measure of crises.

${ }^{28}$ Again, we ran the tests using the ks.test function from base $\mathrm{R}$.
} 
Figure 7: Diffusion, Jump, and Total Variance Estimate Distributions Across Crisis and Non-Crisis Periods from Laeven and Valencia (2013)

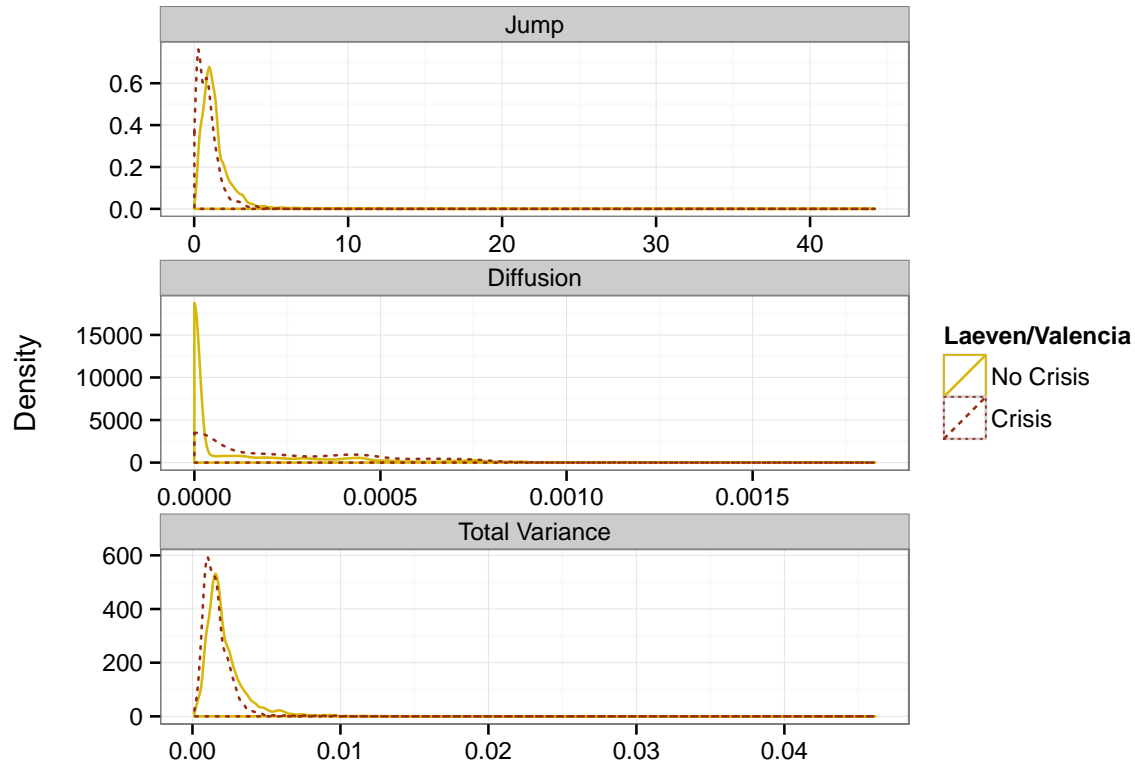

component of Laeven and Valencia's classification-there are a few periods of large positive changes followed by many smaller, often positive, FinStress changes at a high level.

In non-crisis times there may effectively be more noise in economic events about the underlying level of stress, causing relatively large positive and negative swings in perceptions of financial market conditions, e.g. is the failure of one bank indicative of wider problems to come or is it a local event caused by, for example, ineffective management at that particular bank? When crises occur, the information used to create perceptions of financial market stress is clearer. Think for example of Lehman Brother's collapse and the continually bad news that followed. During a crisis, initial shocks are followed by additional bad news that reinforces perceptions of heightened stress. During non-crisis times, a possible shock could be relatively quickly followed by good news, returning perceptions of stress to a lower level.

\section{Application: Financial Crisis Political Budget Cycles}

A clear use of the FinStress Index is as a right-hand variable in regression analyses where the dependent variable is a particular policy choice or government failure time. FinStress could also be used as a dependent 
variable to examine how government partisanship or electoral competitiveness affects perceptions of financial stability. In this section we give an example of how FinStress can be useful as an independent variable to examine political budget cycles during periods of financial market stress.

\subsection{Problems measuring fiscal responses to financial crises}

Fiscal costs to the public of financial stress and crisis is another concept that is notoriously difficult to measure, but substantively important (see Reinhart and Rogoff, 2011). Gandrud and Hallerberg (2015) catalogue many issues with perhaps the most comprehensive data set of fiscal costs: Laeven and Valencia (2013, and their predecessors). Governments significantly increase their use of policies that have obscure budgetary implications during crises (Seiferling and Tareq, 2015). Many of these policies for assisting ailing financial institutions, like guarantees and liquidity assistance, may not involve direct expenditures that are easily attributable to a specific policy choice. Accounting rules differ across time and place (Gandrud and Hallerberg, forthcoming) meaning that a cost in one context may be "hidden debt" (Reinhart and Rogoff, 2011) in another.

We should expect costs to vary according to the amount of stress that politicians believe they face, not just policy-makers' choices. Politicians will, on average, respond more forcefully to resolve what they perceive to be more severe financial market stress in order to achieve the same level of financial stability. We need to be able to account for how severely stressed politicians believe their markets to be when measuring the costs of responding to financial market stress. Similarly, we do not want to exclude periods of stress where politicians use fiscal resources to quell stress before it becomes the type of event that would be viewed as a crisis ex post. Previous research has included binary crisis indicators on the right-hand side of models investigating budgetary choices (Reischmann, forthcoming). However, as we have already seen, crisis severity varies considerably across and within different periods defined as crises. Furthermore, this approach suffers from potential biases from the Type II errors discussed above.

It is substantively interesting whether when costs are realised is endogenous to political conditions. Politicians have some control over the timing of when financial crisis costs are exposed. For example, the United Kingdom's Chancellor of the Exchequer George Osborne announced on 10 June 2015 that the government would begin selling its stake in the Royal Bank of Scotland (RBS)-a bank that had been nationalised during the 2008 crash. The sale would likely be at a substantial loss. ${ }^{29}$ The sale announcement came approximately a month after the United Kingdom's general election in which George Osborne's Conservative Party was

\footnotetext{
${ }^{29}$ See http://www . theguardian. com/business/2015/jun/10/george-osborne-signals-rbs-sell-off-at-mansion-house-speech. Accessed June 2015.
} 
re-elected and won a parliamentary majority. In consequence, if not design, the realisation of these losses from assisting RBS was deferred until after the election, when the government had secured another five years in power before they needed to return to voters.

This event raises an interesting question: what political factors influence when politicians decide to make the costs of a financial crisis public? To the extent that they can control cost realisation timing, do they, like George Osborne, choose to reveal costs when they are sitting on the safe side of an election? We can use FinStress to help us answer these questions.

\subsection{Estimating 'off-trend' financial crisis debt}

We first need to consider what aspect of governments' fiscal positions voters, and so office-seeking politicians, are primarily concerned about during crises. Gandrud and Hallerberg (forthcoming) argue that voters likely pay the most attention to debt increases. ${ }^{30}$ Taxpaying voters are wary of debt increases as they might lead to tax increases. Voters who benefit more from government spending are also concerned about debt increases as these might lead to spending cuts. We would therefore expect office-seeking politicians to try to shift gross debt increases until after elections, which is when they are under the least threat of being removed from office by displeased voters.

We can think of the timing of debt changes in response to crises as having two components, especially in advanced democracies. The first is largely a function of crisis severity and economic events that for our purposes here could be thought of as random. Voters are not only worried about debt increases. They are also concerned with general economic well-being, and therefore want governments to restore financial market stability when markets become unstable (Rosas, 2009). Stabilising markets with policies such as as guaranteeing deposits and providing liquidity assistance to banks on average defers costs more than alternatives such as direct bank recapitalisations. However, governments do not have complete control over economics events and so lack complete control over when contingent liabilities are realised. Additionally, we would expect debts to be higher when the economy is doing worse overall, regardless of whether or not this is caused by financial crises. Especially in advanced democracies, previous policy decisions have created automatic stabilisers, like unemployment insurance, that are more costly during economic downturns. ${ }^{31}$

The second component is made up of costs whose timing can be more easily effected by political choices.

\footnotetext{
${ }^{30}$ The ECB also notes that most responses to financial crises, at least used in Europe between 2008 and 2014 affect debts not deficits (European Central Bank, 2015, 78).

${ }^{31}$ For example, the ECB found that during the 2008-2014 period most of the increase in government debts was caused primarily by positive interest rate differentials, automatic stabilisers and non-finance system discretionary spending, while support to the financial system was particularly important in certain countries (European Central Bank, 2015, 77).
} 
Table 5: Estimating Off-Trend Central Government Debt in Response to Financial Market Stress

\begin{tabular}{lc}
\hline \hline & Dependent variable: \\
\cline { 2 - 2 } & Central Gov. Debt \% GDP $(2005$ GDP rebased $)$ \\
\hline Debt $_{t-1}$ & $0.902^{* * *}$ \\
& $(0.045)$ \\
FinStress & $19.360^{* * *}$ \\
& $(4.773)$ \\
Output Gap & -0.055 \\
& $(0.136)$ \\
Constant & -1.551 \\
& $(3.600)$ \\
\hline country fixed effects & Yes \\
\hline Observations & 264 \\
$\mathrm{R}^{2}$ & 0.974 \\
Adjusted $\mathrm{R}^{2}$ & 0.970 \\
Residual Std. Error & 5.706 \\
F Statistic & $257.595^{* * *}$ \\
\hline \hline Note: & ${ }^{*} \mathrm{p}<0.1 ;{ }^{* *} \mathrm{p}<0.05 ;{ }^{* * *} \mathrm{p}<0.01$ \\
& Standard errors in parentheses.
\end{tabular}

The RBS example case discussed above is a good example. While the realisation of contingent liabilities is not as controllable as timing when to privatise a nationalised bank, choosing to use contingent liability creating policies rather than direct liability creating policies does give politicians the ability to defer at least some costs.

For simplicity, we refer to the first component of crisis debt realisation timing as the 'trend' debt response for advanced democracies at a given stress level. We refer to deviations from this trend as 'off-trend'.

To estimate 'off-trend' government debt changes in response to financial crises, we ran a partial adjustment panel regression with central government debt as a percentage of GDP as the dependent variable. This variable is from the World Bank's Development Indicators. ${ }^{32}$ The results are shown in Table 5 . The model includes lagged central government debt as a percentage of GDP to control for serial autocorrelation, as

\footnotetext{
32 http://data.worldbank.org/data-catalog/world-development-indicators. Accessed June 2015. It was originally recorded as a percentage of the same year GDP. To strip out GDP changes-we are only interested in changes to the numerator not the denominator-, we rebased the variable in terms of each country's 2005 GDP. The GDP variable was from the OECD.
} 
well as output gaps to control for economic fluctuations. The model also includes country fixed effects. The output gap is from the $\mathrm{OECD}^{33}$ and as such our sample is restricted to developed OECD countries. Due to the other variables being on an annual time scale, we included FinStress as an annual average.

It should be noted that recently Amaglobeli et al. (2015) took a different approach to accounting for crisis severity. They included the non-performing loan ratio in their regressions. This variable was from Laeven and Valencia (2013). However, as Gandrud and O'Keeffe (forthcoming) demonstrate, this statistic is often highly contested and endogenous to the institutional environment. Though, as we saw above, FinStress closely corresponds to observed NPL levels.

As expected, we can see that perceptions of financial market stress are strongly positively associated with higher gross central government debt. Predictions from this model can be considered as the average or 'trend' central government debt at various levels of perceived financial market stress. Residuals from the model can be thought of as how far 'off-trend' debt is in a country-year given a particular level of perceived stress. Despite the strong positive association between stress level and central government debt and the close fit of the model-the adjusted $R^{2}$ is 0.97 -this does not mean that the estimated 'off-trend' debts are substantively inconsequential. In this sample, off-trend debt ranges from -28.5 to 36.4 percent of GDP with an interquartile range of $4.9 .^{34}$

\subsection{Debt increases after elections}

We then examine how politicians' electoral safety may affect changes to 'off-trend' debt. To do this we create a dependent variable of the year-on-year change in the debt residuals. Table 6 shows results from partial correction panel models examining the relationship between electoral safety and changes to off-trend financial stress debt. Our primary covariate of interest is a post-election year dummy developed from Gandrud's (2015) election timing variable. It is set at one in years following elections and zero otherwise. In addition, we are interested in electoral competitiveness as measured by the probability that the plurality party will lose its plurality in the next election. This variable is from Kayser and Lindstädt (2015).

To control for possible omitted variable bias we included a number of other economic and political variables. We included 10 year bond spreads with US 10 year T-bills to control for governments' access to affordable debt financing. This data was gathered from a Bloomberg Terminal. We included the governing party's economic ideology from Beck et al. (2001, updated through 2012). As Broz (2013) and Ha and Kang

\footnotetext{
${ }^{33}$ Data was accessed through https://data.oecd.org/ in June 2015.

${ }^{34}$ Greece and Iceland are notable outliers in this sample. Greece had by far the lowest off-trend debt in 2010 and 2011 when it was under an international bailout program with strict fiscal conditions. Iceland had by far the highest off-trend debt in 2008 during its response to the financial crisis.
} 
Table 6: Estimating Changes in Off-Trend Central Government Debt in Response to Crises

\begin{tabular}{|c|c|c|c|c|c|c|c|}
\hline & \multicolumn{7}{|c|}{ Dependent variable: } \\
\hline & & & & Off-Trend D & & & \\
\hline & (1) & (2) & (3) & (4) & (5) & (6) & (7) \\
\hline$\Delta$ Off-Trend Debt $t-1$ & $\begin{array}{l}-0.409^{* * *} \\
(0.089)\end{array}$ & $\begin{array}{c}-0.393^{* * *} \\
(0.088)\end{array}$ & $\begin{array}{l}-0.350^{* * *} \\
(0.084)\end{array}$ & $\begin{array}{l}-0.418^{* * *} \\
(0.113)\end{array}$ & $\begin{array}{l}-0.325^{* * *} \\
(0.093)\end{array}$ & $\begin{array}{l}-0.299^{* * *} \\
(0.110)\end{array}$ & $\begin{array}{l}-0.317^{* * *} \\
(0.110)\end{array}$ \\
\hline$\Delta$ Off-Trend Spend & & & & & & $\begin{array}{c}0.183 \\
(0.294)\end{array}$ & \\
\hline$\Delta$ Off-Trend Spend $_{t-1}$ & & & & & & & $\begin{array}{c}0.266 \\
(0.663)\end{array}$ \\
\hline Post-Election Yr. & $\begin{array}{l}2.585^{*} \\
(1.463)\end{array}$ & $\begin{array}{r}6.150 * * \\
(2.377)\end{array}$ & $\begin{array}{l}5.546^{* *} \\
(2.267)\end{array}$ & $\begin{array}{c}6.833^{* * *} \\
(2.317)\end{array}$ & $\begin{array}{c}7.099^{* * *} \\
(1.808)\end{array}$ & $\begin{array}{c}7.292^{* * *} \\
(2.099)\end{array}$ & $\begin{array}{l}7.126 * * * \\
(2.091)\end{array}$ \\
\hline Loss Prob. & $\begin{array}{l}-2.428 \\
(5.710)\end{array}$ & $\begin{array}{l}1.706 \\
(6.052)\end{array}$ & $\begin{array}{c}3.962 \\
(3.485)\end{array}$ & $\begin{array}{c}3.804 \\
(3.743)\end{array}$ & $\begin{array}{c}3.391 \\
(2.705)\end{array}$ & $\begin{array}{c}3.452 \\
(3.036)\end{array}$ & $\begin{array}{c}3.288 \\
(3.022)\end{array}$ \\
\hline $10 \mathrm{yr}$ Bond Spread & & & & $\begin{array}{l}-0.006 \\
(0.004)\end{array}$ & $\begin{array}{l}-0.0004 \\
(0.005)\end{array}$ & $\begin{array}{l}-0.003 \\
(0.007)\end{array}$ & $\begin{array}{l}-0.001 \\
(0.006)\end{array}$ \\
\hline Econ Ideology & & & & $\begin{array}{l}-1.101 \\
(0.739)\end{array}$ & $\begin{array}{l}-0.380 \\
(0.552)\end{array}$ & $\begin{array}{l}-0.145 \\
(0.640)\end{array}$ & $\begin{array}{l}-0.185 \\
(0.643)\end{array}$ \\
\hline Political Constraints & & & & $\begin{array}{c}0.361 \\
(5.258)\end{array}$ & $\begin{array}{l}-0.057 \\
(3.827)\end{array}$ & $\begin{array}{l}-0.120 \\
(4.356)\end{array}$ & $\begin{array}{l}-0.301 \\
(4.368)\end{array}$ \\
\hline Fixed FX & & & & $\begin{array}{l}-1.835 \\
(1.452)\end{array}$ & $\begin{array}{c}0.008 \\
(1.072)\end{array}$ & $\begin{array}{c}0.180 \\
(1.351)\end{array}$ & $\begin{array}{c}0.191 \\
(1.353)\end{array}$ \\
\hline Post-Election Yr. * Loss Prob. & & $\begin{array}{l}-12.599^{*} \\
(6.667)\end{array}$ & $\begin{array}{c}-11.413^{*} \\
(6.319)\end{array}$ & $\begin{array}{l}-12.495^{*} \\
(6.468)\end{array}$ & $\begin{array}{l}-12.600^{* *} \\
(4.800)\end{array}$ & $\begin{array}{l}-12.991 * * \\
(5.548)\end{array}$ & $\begin{array}{l}-12.884^{* *} \\
(5.552)\end{array}$ \\
\hline Constant & $\begin{array}{c}0.304 \\
(3.578)\end{array}$ & $\begin{array}{l}-0.738 \\
(3.578)\end{array}$ & $\begin{array}{l}-1.781 \\
(1.186)\end{array}$ & $\begin{array}{c}1.445 \\
(3.286)\end{array}$ & $\begin{array}{l}-0.889 \\
(2.438)\end{array}$ & $\begin{array}{l}-1.546 \\
(3.075)\end{array}$ & $\begin{array}{l}-1.275 \\
(3.066)\end{array}$ \\
\hline Country fixed effects? & Yes & Yes & No & No & No & No & No \\
\hline Include outliers? & & No & No & No & Yes & Yes & Yes \\
\hline $\begin{array}{l}\text { Observations } \\
\mathrm{R}^{2}\end{array}$ & 132 & 132 & 132 & 112 & 104 & 92 & 92 \\
\hline $\begin{array}{l}\mathrm{R}^{2} \\
\text { Adjusted } \mathrm{R}^{2}\end{array}$ & $\begin{array}{l}0.239 \\
0.069\end{array}$ & $\begin{array}{l}0.264 \\
0.091\end{array}$ & $\begin{array}{l}0.177 \\
0.151\end{array}$ & $\begin{array}{l}0.224 \\
0.164\end{array}$ & $\begin{array}{l}0.277 \\
0.216\end{array}$ & $\begin{array}{l}0.269 \\
0.189\end{array}$ & $\begin{array}{l}0.267 \\
0.187\end{array}$ \\
\hline Residual Std. Error & 7.490 & 7.402 & 7.151 & 6.890 & 4.911 & 5.105 & 5.112 \\
\hline F Statistic & 1.403 & $1.522 *$ & $6.834^{* * * *}$ & $3.722 * * *$ & $4.539^{* * *}$ & $3.358^{* * * *}$ & $3.323^{* * *}$ \\
\hline
\end{tabular}

Figure 8: Marginal Effect of Post-Election Year on Off-Trend Debt at Various Electoral Loss Probabilities

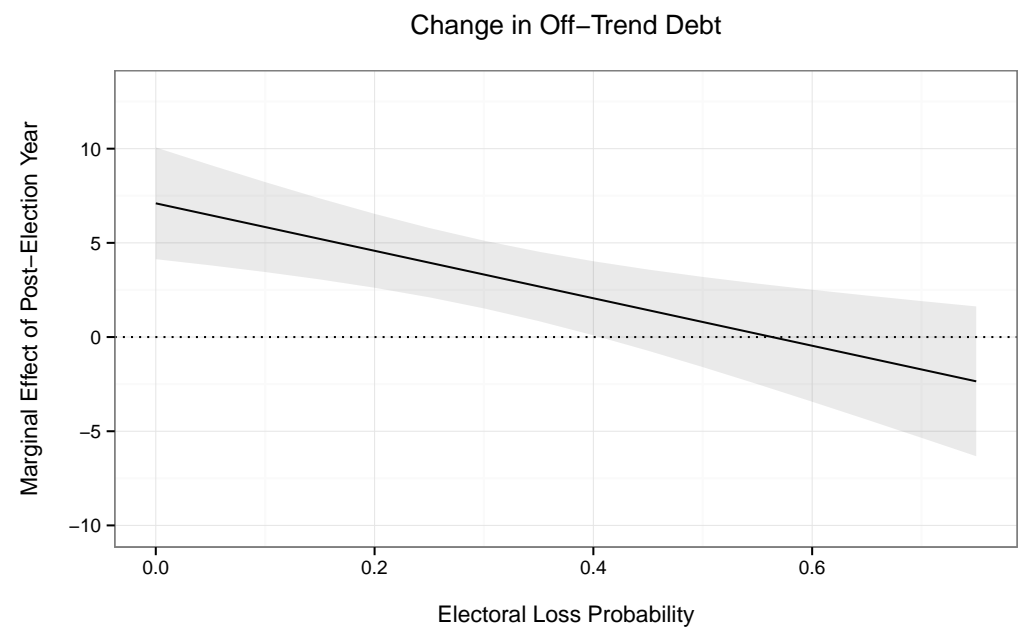

Shaded area represents the $90 \%$ confidence interval.

Plot made using Model 5 in Table 6. 
(2015) suggests, left- and right-wing governments may respond to crises differently. Perhaps, also as Ha and Kang (2015) find in developing countries with fiscal consolidation, governments facing more constraints will be less able to to determine the timing of debt realisation. To control for this, we included a measure of political constraints from (Henisz, 2004, updated through 2011). ${ }^{35}$ Clark and Hallerberg (2000) find that political budget cycles are affected by exchange rate regimes, with fiscal expansions more likely to occur in economies with fixed exchange rates and therefore few if any monetary policy tools at the government's disposal. As such, we tested a binary indicator of whether or not a country had a fixed foreign exchange regime. ${ }^{36}$ Finally, debt may clearly reflect directly disclosed government spending. So we included an offtrend government economic policy spending indicator constructed in the same way as our off-trend debt indicator using spending data from the OECD. ${ }^{37}$

Across the various model specifications we found that off-trend debt from perceived financial market stress is estimated to increase in post-election years. We further interacted the post-election year variable with electoral loss probability and found that off-trend debt increases after elections especially occur in countries when there is a lower electoral loss probability (see Figure 8). In countries with very low loss probabilities, the off-trend debt increases on average by above 5 percentage points of GDP in post-election years. At higher loss probabilities the positive effect becomes insignificantly different from zero, meaning that when there is a higher probability of losing in the next election that governments do not have higher off-trend debt increases. These results hold even when we exclude Greece and Iceland, which are significant negative and positive off-trend debt outliers, respectively.

These results indicate that the timing of off-trend government debt increases in response to financial crises may indeed be endogenous to politicians' electioneering, thus creating something of a financial crisis political budget cycle. Very safe politicians, i.e. those who have just won an election and are less likely to lose the next one, are more likely to make public the costs of responding to financial market stress.

\section{Conclusions}

We have introduced a novel continuous measure of perceived financial market stress-FinStress-, compared it to prior measures of financial crisis and stress, and provided one application showing how our continuous measure could be used in future research to examine fiscal decisions in response to financial crises. Unlike

\footnotetext{
${ }^{35}$ We specifically used the POLCONIII variable.

${ }^{36}$ We coded a country as having a fixed exchange rate regime if it was in the Eurozone or had pegged their currency to the Euro.

${ }^{37}$ Data was accessed through https://data.oecd.org/ in June 2015.
} 
previous measures, FinStress does not focus exclusively on financial market stress that, in hindsight, was not dealt with effectively by policy-makers. This could allow future researchers to examine what policies were effective at preventing full blown crises and what political conditions were conducive to implementing these policies. Being an indicator of perceived and real-time stress, rather than post hoc evaluations of policy decisions in response to market events, similarly provides a much more relevant indicator for understanding policy-makers' decision-making process. FinStress should be used instead of previous second-best measures of financial market stress by researchers aiming to understand why and how policy-makers respond to financial market stress.

Our work has implications for the wider research community as well. We have demonstrated how researchers could construct continuous indicators of other political and economic phenomena using machine learning and text analysis. Once a text gathering and analysis "pipeline" (Leek and Peng, 2015) has been developed and validated, researchers using this approach can quickly and cost effectively develop and update new indicators. This approach is especially useful in comparison to time-consuming, expensive, and irreproducible human coding techniques.

\section{References}

Amaglobeli, David, Nicolas End, Mariusz Jarmuzek and Geremia Palomba. 2015. "From Systemic Banking Crises to Fiscal Costs: Risk Factors." IMF Working Paper WP/15/166:1-43.

Andrianova, Svetlana, Badi Baltagi, Panicos Demetriades and David Fielding. 2014. "Why Do African Banks Lend So Little?" Oxford Bulletin of Economics and Statistics 77(3):339-359.

Andrianova, Svetlana, Badi Baltagi, Thorsten Beck, Panicos Demetriades, David Fielding, Stephen Hall, Steven Koch, Robert Lensink, Johan Rewilak and Reter Rousseau. 2015. "A New International Database on Financial Fragility." University of Leicester Department of Economics Working Paper pp. 1-54.

Beck, Thorsten, George Clarke, Alberto Groff, Philip Keefer, and Patrick Walsh. 2001. "New Tools in Comparative Political Economy: The Database of Political Institutions." World Bank Economic Review (1).

Beck, Thorsten, Olivier De Jonghe and Glenn Schepens. 2013. "Bank competition and stability: crosscountry heterogeneity." Journal of financial Intermediation 22(2):218-244. 
Bernhard, William and David Leblang. 2008. "Cabinet Collapses and Currency Crashes." Political Research Quarterly 61(3):517-531.

Breiman, Leo. 2001. "Random Forests." Machine Learning 45(1):5-32.

Broz, J. Lawrence. 2013. Partisan Financial Cycles. In Politics in the New Hard Times: The Great Recession in Comparative Perspective, ed. David L. Lake and Miles Kahler. Ithaca: Cornell University Press.

Carpenter, SR and WA Brock. 2011. "Early warnings of unknown nonlinear shifts: a nonparametric approach." Ecology 92:2196-2201.

Chaudron, Raymond and Jakob de Haan. 2014. "Dating Banking Crises Using Incidence and Size of Bank Failures: Four Crises Reconsidered." Journal of Financial Stability pp. 1-34.

Chwieroth, Jeffrey and Andrew Walter. 2015. "Great Expectations, Veto Players, and the Changing Politics of Banking Crises." LSE Systemic Risk Centre Discussion Paper Series . http://www.systemicrisk.ac.uk/publications/discussion-papers/ great-expectations-veto-players-and-changing-politics-banking-crises.

Čihák, Martin and Heiko Hesse. 2010. "Islamic banks and financial stability: An empirical analysis." Journal of Financial Services Research 38(2-3):95-113.

Clark, William Roberts and Mark Hallerberg. 2000. "Mobile capital, domestic institutions, and electorally induced monetary and fiscal policy." American Political Science Review 94(02):323-346.

Copelovitch, Mark, Christopher Gandrud and Mark Hallerberg. 2015. "Financial Regulatory Transparency, International Institutions, and Borrowing Costs." Working Paper .

Crespo-Tenorio, Adriana, Nathan M Jensen and Guillermo Rosas. 2014. "Political Liabilities: Surviving Banking Crises." Comparative Political Studies 47(7):1047-1074.

Dakos, Vasilis and Leo Lahti. 2013. "R Early Warning Signals Toolbox." The R Project for Statistical Computing . http://cran.r-project.org/web/packages/earlywarnings/index.html.

Dakos, Vasilis, Stephen R Carpenter, William A Brock, Aaron M Ellison, Vishwesha Guttal, Anthony R Ives, Sonia Kéfi, Valerie Livina, David A Seekell, Egbert H van Nes and Marten Scheffer. 2012. "Methods for Detecting Early Warnings of Critical Transitions in Time Series Illustrated Using Simulated Ecological Data." PLoS ONE 7(7):e41010-20. 
Dhillon, I. S. and D. S. Modha. 2001. "Concept decompositions for large sparse text data using clustering." Machine Learning 42(1):143-175.

European Central Bank. 2015. "The fiscal impact of financial sector support during the crisis." ECB Economic Bulletin 6:1-14.

Feinerer, Ingo and Kurt Hornik. 2015. tm: Text Mining Package. R package version 0.6-1.

URL: http://CRAN.R-project.org/package $=t m$

Fielding, David and Johan Rewilak. 2015. "Credit booms, financial fragility and banking crises." Economics Letters pp. 1-14.

Galasso, Vincenzo. 2012. "The role of political partisanship during economic crises." Public Choice 158(12):143-165.

Gandrud, Christopher. 2013. "The diffusion of financial supervisory governance ideas." Review of International Political Economy 20(4):881-916.

Gandrud, Christopher. 2014. "Competing Risks and Deposit Insurance Governance Convergence." International Political Science Review 35:197-215.

Gandrud, Christopher. 2015. "Corrections and Refinements to the Database of Political Institutions' yrcurnt Election Timing Variable." The Political Methodologist 22(2):2-4.

Gandrud, Christopher and Mark Hallerberg. 2015. "When All is Said and Done: Updating 'Elections, Special Interests, and Financial Crisis'." Research and Politics 2(3):1-9.

Gandrud, Christopher and Mark Hallerberg. forthcoming. "Statistical Agencies and Responses to Financial Crises: Eurostat, Bad Banks, and the ESM." West European Politics .

Gandrud, Christopher and Mícheál O'Keeffe. forthcoming. "Information and Financial Crisis Policymaking." Journal of European Public Policy .

Grimmer, Justin and Brandon M Stewart. 2013. "Text as Data: The Promise and Pitfalls of Automatic Content Analysis Methods for Political Texts." Political Analysis 21(3):267-297.

Ha, Eunyoung and Myung-koo Kang. 2015. "Government Policy Responses to Financial Crises: Identifying Patterns and Policy Origins in Developing Countries." World Development 68:264-281. 
Hallerberg, Mark and Carlos Scartascini. 2013. "When Do Governments Improve Fiscal Institutions? Lessons from Financial Crisis and Fiscal Reform in Latin America." Working Paper.

Hallerberg, Mark and Joachim Wehner. 2013. "The Technical Competence of Economic Policy-Makers in Developed Democracies." SSRN . Available at: http://ssrn.com/abstract=2191490.

Henisz, Witold Jerzy. 2004. "Political Institutions and Policy Volatility." Economics and Politics 16(1):1-27.

Herrera, Helios, Guillermo Ordoñez and Christoph Trebesch. 2014. "Political Booms, Financial Crises." NBER Working Paper Series pp. 1-52.

Hicken, Allen, Shanker Satyanath and Ernest Sergenti. 2005. "Political Institutions and Economic Performance: The Effects of Accountability and Obstacles to Policy Change." American Journal of Political Science 49(4):897-907.

Honohan, Patrick and Daniela Klingebiel. 2000. "Controling the Fiscal Costs of Banking Crises." World Bank Working Paper (2441).

Honohan, Patrick and Daniela Klingebiel. 2003. "The fiscal cost implications of an accommodating approach to banking crises." Journal of Banking and Finance 27(8):1539-1560.

Ishwaran, H. and U.B. Kogalur. 2015. Random Forests for Survival, Regression and Classification (RF-SRC). $\mathrm{R}$ package version 1.6.1.

URL: http://cran.r-project.org/web/packages/randomForestSRC/

Jing, Zhongbo, Jakob de Haan, Jan Jacobs and Haizhen Yang. 2015. "Identifying banking crises using money market pressure: New evidence for a large set of countries." Journal of Macroeconomics 43(C):1-20.

Jones, Zachary and Fridolin Linder. 2015. "Exploratory Data Analysis using Random Forests." Paper presented at the Annual MPSA Conference.

Karatzoglou, Alexandros, Alex Smola, Kurt Hornik and Achim Zeileis. 2004. "kernlab - An S4 Package for Kernel Methods in R." Journal of Statistical Software 11(9):1-20.

URL: http://www.jstatsoft.org/v11/i09/

Kayser, Mark Andreas and Arndt Leininger. 2015. "Vintage Errors: Do Real-Time Economic Data Improve Election Forecasts?" Research and Politics 2(3). 
Kayser, Mark Andreas and René Lindstädt. 2015. "A Cross-National Measure of Electoral Competitiveness." Political Analysis 23(2):242-253.

Keefer, Philip. 2007. "Elections, Special Interests, and Financial Crisis." International Organization 61(3):607-641.

Kleibl, Johannes. 2013. "The Politics of Financial Regulatory Agency Replacement." Journal of International Money and Finance 75(2):552-566.

Kou, S.G. 2008. Jump-Diffusion Models for Asset pricing in financial engineering. Vol. 15 Elsevier pp. 72116.

Laeven, Luc and Fabián Valencia. 2008. "Systemic Banking Crisis: A New Database." IMF Working Paper (WP/08/224).

Laeven, Luc and Fabian Valencia. 2010. "Resolution of Banking Crises: The Good, the Bad, and the Ugly." IMF Working Paper 10/146.

Laeven, Luc and Fabián Valencia. 2012. "Systemic Banking Crises Database: An Update ." IMF Working Paper (WP/12/163).

Laeven, Luc and Fabián Valencia. 2013. "Systemic Banking Crisis Database." IMF Economic Review $61(2): 225-270$.

Laeven, Luc and Ross Levine. 2009. "Bank governance, regulation and risk taking." Journal of Financial Economics 93(2):259-275.

Leek, Jeffrey T and Roger D Peng. 2015. "P values are just the tip of the iceberg." Nature 520:612.

Lepetit, Laetitia and Frank Strobel. 2013. "Bank insolvency risk and time-varying Z-score measures." Journal of International Financial Markets, Institutions and Money 25:73-87.

Lodhi, Huma, Craig Saunders, John Shawe-Taylor, Nello Cristianini and Chris Watkins. 2002. "Text classification using string kernels." The Journal of Machine Learning Research 2:419-444.

MacIntyre, Andrew. 2001. "Institutions and Investors: The Politics of the Economic Crisis in Southeast Asia." International Organization 55(1):81-122.

Minhas, Shahryar, Jay Ulfelder and Michael D Ward. 2015. "Mining texts to efficiently generate global data on political regime types." Research \& Politics 2(3):1-8. 
Montinola, Gabriella R. 2003. "Who Recovers First?: Banking Crises Resolution in Developing Countries." Comparative Political Studies 36(5):541-574.

Pepinsky, Thomas B. 2012. "The Global Economic Crisis and the Politics of Non-Transitions." Government and Opposition 47(02):135-161.

R Core Team. 2015. R: A Language and Environment for Statistical Computing. Vienna, Austria: R Foundation for Statistical Computing.

URL: http://www.R-project.org/

Reinhart, Carmen and Kenneth Rogoff. 2009. This Time is Different: Eight Centuries of Financial Folly. Princeton: Princeton University Press.

Reinhart, Carmen and Kenneth Rogoff. 2010. "This Time is Different Chartbook: Country Histories on Debt, Default. and Financial Crises." NBER Working Paper (15815). Data available at http://www. carmenreinhart.com/data/. Accessed February 2014.

Reinhart, Carmen M. and Kenneth S. Rogoff. 2011. "From Financial Crash to Debt Crisis." American Economic Review 101(5):1676-1706.

Reischmann, Markus. forthcoming. "Creative accounting and electoral motives: Evidence from OECD countries." Journal of Comparative Economics pp. 1-38.

Rodrik, Dani. 1999. "Where Did All the Growth Go? External Shocks, Social Conflict, and Growth Collapses." Journal of Economic Growth 4:385-412.

Romer, Christina and David Romer. 2015. "New Evidence on the Impact of Financial Crises in Advanced Countries." pp. 1-65. http://eml.berkeley. edu// cromer/RomerandRomerFinancialCrises.pdf. Accessed April 2015.

Rosas, Guillermo. 2006. "Bagehot or Bailout? An Analysis of Government Responses to Banking Crises." American Journal of Political Science 50(1):175-191.

Rosas, Guillermo. 2009. Curbing Bailouts: Bank Crises and Democratic Accountability in Comparative Perspective. Ann Arbor: The University of Michigan Press.

Roy, A.D. 1952. "Safety First and the Holding of Assets." Econometrica 20:431-449. 
Satyanath, Shanker. 2006. Globalization, Politics, and Financial Turmoil: Asia's Banking Crisis. Cambridge: Cambridge University Press.

Scholkopf, B., A. Smola and K. Muller. 1998. "Nonlinear Component Analysis as a Kernel Eigenvalue Problem." Neural Computation 10:1299-1319.

Seiferling, Mike and Shamsuddin Tareq. 2015. "Fiscal Transparency and the Performance of Government Financial Assets." IMF Working Paper (WP/15/9):1-25.

Spirling, Arthur. 2012. "U.S. Treaty Making with American Indians: Institutional Change and Relative Power, 1784-1911." American Journal of Political Science 56(1):84-97.

Uhde, André and Ulrich Heimeshoff. 2009. "Consolidation in banking and financial stability in Europe: Empirical evidence." Journal of Banking 83 Finance 33(7):1299-1311.

Von Hagen, Jorgen and T. Ho. 2007. "Money market pressure and the determinants of banking crises." Journal of Money, Credit, and Banking 39:1037-1066.

Weber, Anke. 2012. "Stock-Flow Adjustments and Fiscal Transparency: A Cross-Country Comparison." IMF Working Paper (WP/12/39):1-19.

Wibbels, Erik and Kenneth Roberts. 2010. "The Politics of Economic Crisis in Latin America." Studies in Comparative International Development 45(4):383-409.

World Bank. 2013. "The Global Financial Development Database.". http://data.worldbank.org/ data-catalog/global-financial-development. Accessed June 2015.

Zhang, Rui, Wenjian Wang and Yichen Ma. 2010. "Approximations of the standard principal components analysis and kernel PCA." Expert Systems with Applications 37(9):6531-6537. 


\section{Online Appendix}

\subsection{Correlations Between FinStress and Camel Variables}

Figure 9: Correlation between Annual FinStress Mean Scores and CAMEL Variables from Andrianova et al. (2015)

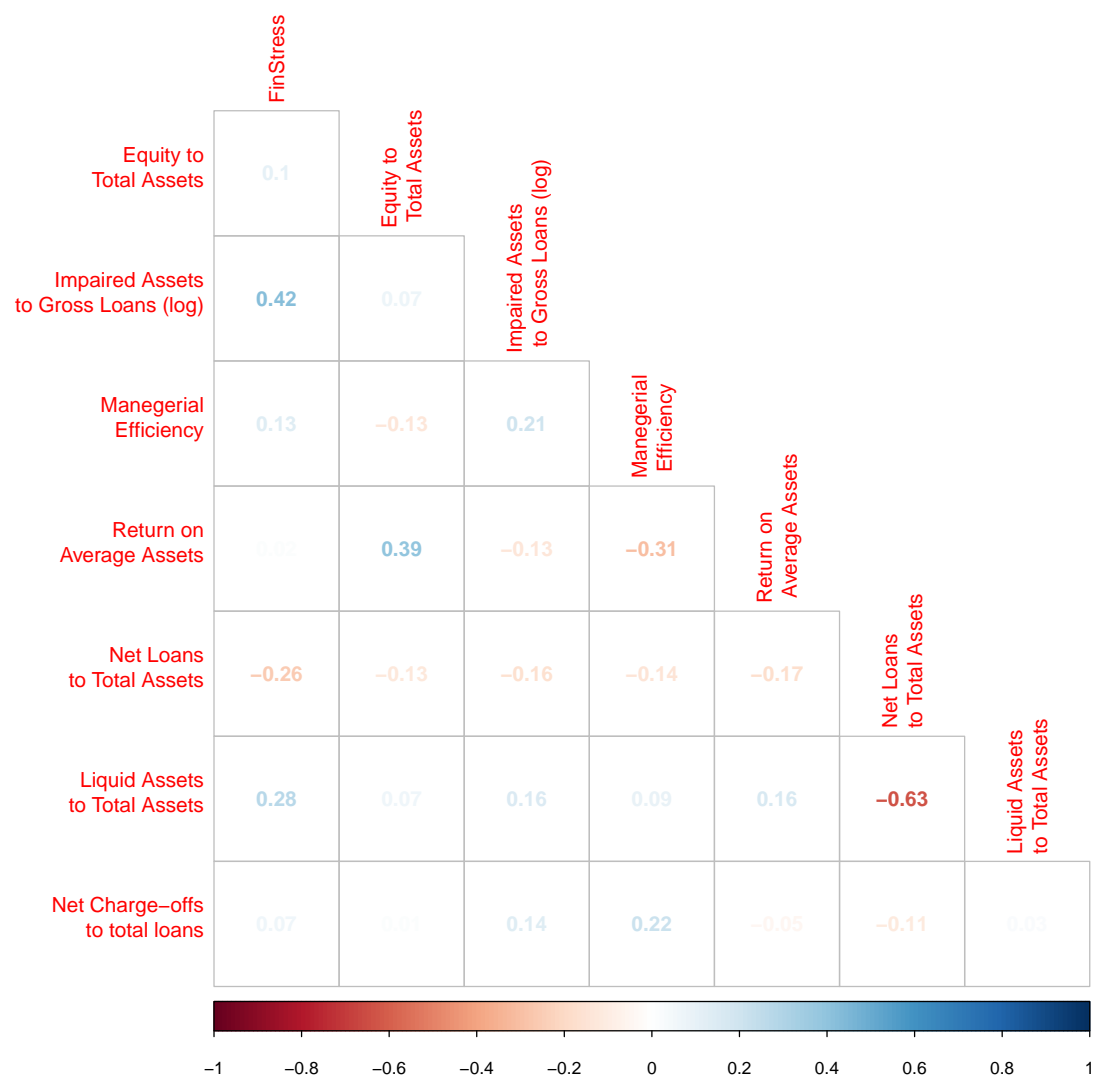

\section{Developed vs. developing countries}

Developing countries often lack strong financial institutions and systems. Facing a very risky pool of borrowers, banks tend to make fewer loans (Andrianova et al., 2014). So we should expect them to face generally tighter credit market conditions than developed countries.

The left panel of Figure 10 shows average stress levels in developed vs. developing countries that Laeven 
Figure 10: Comparison of Mean FinStress Scores in High vs. Low and Medium Income Countries

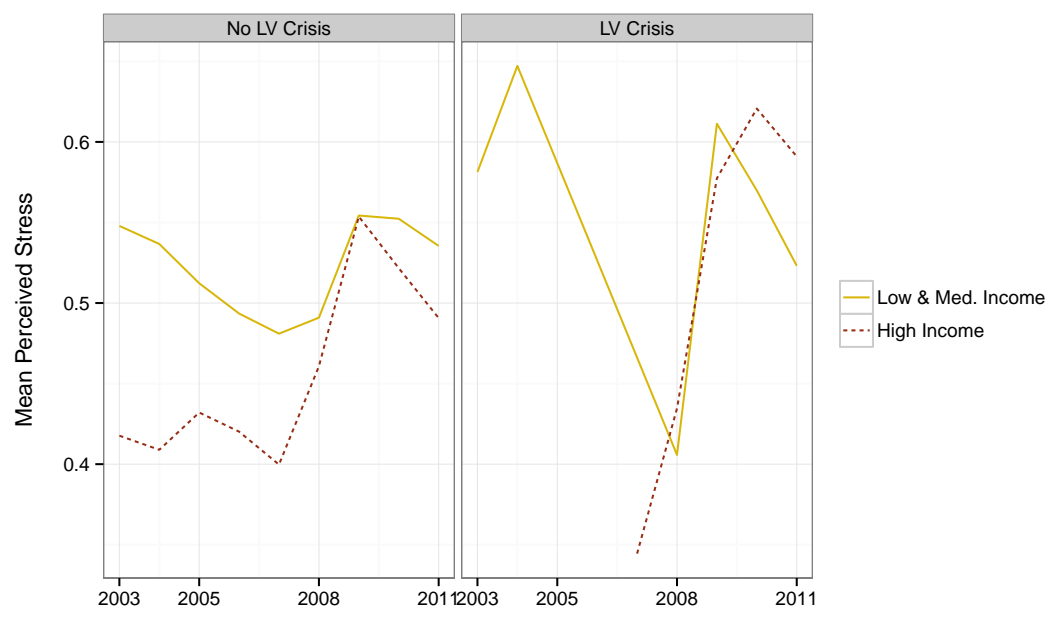

Plot excludes Uruguay, which was a substantial outlier with a much lower average FinStress score during what Laeven and Valencia classify as a crisis than all other developing countries.

and Valencia code as not being in crisis-indicates that there is a difference in the level of perceived financial market stress in developed and developing countries from 2003 to 2008. Developing countries on average have higher FinStress scores. For example, the mean score in middle and low income countries (as classified by the World Bank) is 0.53 in 2005, a level developed countries only reached after the collapse of Lehman Brothers in 2008. ${ }^{38}$ The mean levels across the two groups converge in the Global Financial Crisis. The distribution of FinStress scores in these two groups of countries across the sample is significantly different in the expected direction in the sample using one-sided Kolmogorov-Smirnov tests. ${ }^{39}$

Nonetheless, during periods when the binary Laeven and Valencia code as being a crisis, i.e. implement policy responses to financial market stress, the two sets of scores are very similar (see the right-panel of Figure 10). Apart from 2007 and 2008 where the binary measures have significant "annual rounding error", ${ }^{40}$ on average countries in crisis have FinStress scores above about 0.55. It appears that while developed countries have more stressed financial markets than developed countries that on average, developed and developing countries have clear policy responses to financial market stress when their FinStress scores are above about 0.55 .

\footnotetext{
${ }^{38}$ The 2005 mean for high income countries is 0.44

${ }^{39}$ We ran the tests using the ks.test function from base $\mathrm{R}$.

${ }^{40}$ They include both less and more stressed portions of a year as a crisis
} 


\section{Predicting Measures of Financial Market Stress with Z-Scores}

Table 7: Do Z-Scores Predict Perceived Financial Market Stress?

\begin{tabular}{lc}
\hline \hline & Dependent variable: \\
\cline { 2 - 2 } & Annual Mean FinStress \\
\hline Annual Mean FinStress (lag) & $0.339^{* * *}$ \\
& $(0.023)$ \\
Z-Score (lag) & 0.0002 \\
& $(0.0004)$ \\
\hline Fixed effects? & \\
Observations & Yes \\
$\mathrm{R}^{2}$ & 1,464 \\
Adjusted $\mathrm{R}^{2}$ & 0.149 \\
F Statistic & 0.130 \\
\hline \hline & $112.040^{* * *}(\mathrm{df}=2 ; 1278)$ \\
Note: & ${ }^{*} \mathrm{p}<0.1 ;{ }^{* *} \mathrm{p}<0.05 ; * * * \mathrm{p}<0.01$
\end{tabular}

\section{Selection of Literature Including Cross-Country Measures of Financial or Bank- ing Market Crisis}

Table 8: Selected Literature Review of Political Institutions and Financial Crisis (Political Outcomes)

\begin{tabular}{|c|c|c|c|}
\hline Work & Crisis Type & Key Arguments/Findings & Crisis Data Sources \\
\hline $\begin{array}{l}\text { Bernhard and Leblang } \\
(2008)\end{array}$ & Currency crisis & $\begin{array}{l}\text { - Changes in the probability that cabinets will collapse condition } \\
\text { the probability of speculative attacks. } \\
\text { - Higher probability of a speculative attack decreases the prob- } \\
\text { ability of calling strategic elections. }\end{array}$ & $\begin{array}{l}\text { Own data aggregated } \\
\text { from multiple sources }\end{array}$ \\
\hline $\begin{array}{l}\text { Chwieroth and Walter } \\
\text { (2015) }\end{array}$ & Banking crises & $\begin{array}{l}\text { - Probability of government survival during crises changed over } \\
\text { time as expectations changed about what governments should do } \\
\text { to respond. } \\
\text { - Governments with more veto players after the inter-war period } \\
\text { are treated more harshly by voters. }\end{array}$ & $\begin{array}{l}\text { Reinhart and Rogoff } \\
(2010)\end{array}$ \\
\hline $\begin{array}{l}\text { Crespo-Tenorio, Jensen } \\
\text { and Rosas (2014) }\end{array}$ & Banking crisis & $\begin{array}{l}\text { - Increasing globalization weakens the accountability link be- } \\
\text { tween politicians and voters. } \\
\text { - Incumbents in open capital economies are more likely to survive } \\
\text { a crisis, than those in closed economies. }\end{array}$ & $\begin{array}{l}\text { Laeven and Valencia } \\
(2010)\end{array}$ \\
\hline Montinola (2003) & Banking crisis & $\begin{array}{l}\text { - IMF credits decrease the probability of resolving banking crises. } \\
\text { - The decisiveness of a political regime significantly influences } \\
\text { the probability of emerging from systemic distress, though this } \\
\text { depends on whether the crisis is moderate or severe. }\end{array}$ & $\begin{array}{l}\text { Own data aggregated } \\
\text { from multiple sources }\end{array}$ \\
\hline Pepinsky (2012) & Banking crisis & $\begin{array}{l}\text { - Two factors-incumbent governments' responsibility for the cur- } \\
\text { rent crisis and their responsiveness to its domestic economic } \\
\text { effects-shape the political effects of the global economic crisis. }\end{array}$ & $\begin{array}{l}\text { Laeven and Valencia } \\
(2010)\end{array}$ \\
\hline
\end{tabular}


Table 9: Selected Literature Review of Political Institutions and Financial Crisis (Crisis Occurrence, Policy Choices/Policy Outcomes)

\begin{tabular}{|c|c|c|c|}
\hline Work & Crisis Type & Key Arguments/Findings & Crisis Data Sources \\
\hline Broz (2013) & Banking crisis & $\begin{array}{l}\text { - In OECD countries right-wing governments pursue policies that } \\
\text { lead to financial instability. Voters respond to resulting crises by } \\
\text { voting in left-wing governments. }\end{array}$ & $\begin{array}{l}\text { Reinhart and Rogoff (2009); } \\
\text { Laeven and Valencia (2012) }\end{array}$ \\
\hline Galasso (2012) & $\begin{array}{l}\text { Financial and eco- } \\
\text { nomic crises }\end{array}$ & - Governments respond to financial crises by increasing regulation. & $\begin{array}{l}\text { Dummy based on OECD out- } \\
\text { put gap below }-3.4 \%\end{array}$ \\
\hline Gandrud $(2013,2014)$ & Banking crises & $\begin{array}{l}\text { - Best practice financial governance institutional designs are more } \\
\text { likely to be adopted during crises when there is high uncertainty } \\
\text { about policy choices and outcomes. }\end{array}$ & $\begin{array}{l}\text { Laeven and Valencia (2008); } \\
\text { Reinhart and Rogoff (2010) }\end{array}$ \\
\hline Ha and Kang (2015) & - Banking crisis & $\begin{array}{l}\text { Developing countries respond to crises with fiscal and monetary } \\
\text { tightening, which was moderated by political constraints, left ide- } \\
\text { ology governing parties, and up coming elections. }\end{array}$ & Laeven and Valencia (2008). \\
\hline $\begin{array}{l}\text { Hallerberg and Scar- } \\
\text { tascini }(2013)\end{array}$ & $\begin{array}{l}\text { Banking, debt } \\
\text { crises }\end{array}$ & $\begin{array}{l}\text { - Banking crises reduce the probability of fiscal reforms, but the } \\
\text { longer a crisis lasts and if it becomes a sovereign debt crisis the } \\
\text { the probability of reform increases. } \\
\text { - Countries with more personalistic voting are more likely to re- } \\
\text { form. }\end{array}$ & $\begin{array}{l}\text { Laeven and Valencia (2012) } \\
\text { for Latin American countries }\end{array}$ \\
\hline $\begin{array}{l}\text { Hallerberg and Wehner } \\
\text { (2013) }\end{array}$ & $\begin{array}{l}\text { Banking, currency, } \\
\text { debt crises }\end{array}$ & $\begin{array}{l}\text { - Some evidence that more technically competent ministers of fi- } \\
\text { nance are appointed during debt crises. Not much robust evidence } \\
\text { for other effects of crisis on the technical competency of economic } \\
\text { policy-makers. }\end{array}$ & Laeven and Valencia (2012) \\
\hline $\begin{array}{l}\text { Hicken, Satyanath and } \\
\text { Sergenti }(2005)(2005)\end{array}$ & Growth shocks & $\begin{array}{l}\text { - The size of the winning coalition is positively associated with } \\
\text { growth recoveries following forced devaluations. }\end{array}$ & $\begin{array}{l}\text { Own data aggregated from } \\
\text { multiple sources }\end{array}$ \\
\hline Keefer (2007) & Banking crises & $\begin{array}{l}\text { - Higher electoral competitiveness leads to faster and less costly } \\
\text { crisis responses. } \\
\text { - Checks and balances not associated with crisis policy choices or } \\
\text { outcomes. }\end{array}$ & $\begin{array}{l}\text { Modified Honohan and } \\
\text { Klingebiel (2003) }\end{array}$ \\
\hline Kleibl (2013) & Banking crisis & $\begin{array}{l}\text { - Responses to regulatory failures are conditioned by the level of } \\
\text { public ownership in the banking sector. }\end{array}$ & $\begin{array}{l}\text { Laeven and Valencia (2010); } \\
\text { Reinhart and Rogoff (2009) } \\
\text { for OECD countries }\end{array}$ \\
\hline MacIntyre (2001) & Financial crises & - U-shaped relationship between veto players and crisis outcomes & $\begin{array}{l}\text { Own data aggregated from } \\
\text { multiple sources }\end{array}$ \\
\hline $\begin{array}{l}\text { Reischmann (forthcom- } \\
\text { ing) }\end{array}$ & Banking crises & $\begin{array}{l}\text { - Creative accounting as measured by changes in the stock flow } \\
\text { adjustment occurs more during financial crises, though effect may } \\
\text { be swallowed up by the period fixed effects in his regressions as } \\
\text { crises are highly correlated with time in his sample. }\end{array}$ & Laeven and Valencia (2012) \\
\hline Rodrik (1999) & Growth shock & $\begin{array}{l}\text { - Many veto players, if organized to manage conflicts, will result } \\
\text { in more appropriate and quickly implemented crisis management } \\
\text { policies. }\end{array}$ & $\begin{array}{l}\text { Own data aggregated from } \\
\text { multiple sources }\end{array}$ \\
\hline Rosas $(2006,2009)$ & Banking crisis & $\begin{array}{l}\text { - Democratic regimes have fewer bailouts. } \\
\text { - Central bank independence and transparency lead to fewer } \\
\text { bailouts. }\end{array}$ & $\begin{array}{l}\text { Modified Honohan and } \\
\text { Klingebiel }(2000)\end{array}$ \\
\hline $\begin{array}{l}\text { Seiferling and Tareq } \\
(2015)\end{array}$ & Banking crisis & $\begin{array}{l}\text { - Find advanced economies governments extend more loans and pur- } \\
\text { chase more equities in temporarily insolvent firms during financial } \\
\text { crisis than emerging market governments. }\end{array}$ & $\begin{array}{l}\text { Laeven and Valencia (2010) } \\
\text { via Weber (2012) }\end{array}$ \\
\hline Satyanath (2006) & Banking crises & $\begin{array}{l}\text { - Executives without 'banking cronies' and that are not prevented } \\
\text { from appointing their own bureaucrats by many veto players are } \\
\text { more likely to have stringent financial regulation that prevents } \\
\text { crises. }\end{array}$ & $\begin{array}{l}\text { Case studies of } 7 \text { East Asian } \\
\text { countries using own data }\end{array}$ \\
\hline $\begin{array}{l}\text { Wibbels and Roberts } \\
(2010)\end{array}$ & $\begin{array}{l}\text { Currency, growth, } \\
\& \text { fiscal crises }\end{array}$ & $\begin{array}{l}\text { - Unions and strong left parties are more associated with crises, } \\
\text { though combined strong unions-left parties may alleviate inflation- } \\
\text { ary crises. }\end{array}$ & $\begin{array}{l}\text { Own data aggregated from } \\
\text { multiple sources for } 17 \text { Latin } \\
\text { American countries }\end{array}$ \\
\hline
\end{tabular}

